\title{
Acetylene hydrochlorination over supported ionic liquid phase (SILP) gold-based catalyst: Stabilization of cationic Au species via chemical activation of hydrogen chloride and corresponding mechanisms
}

\author{
Jia Zhao a,*, Saisai Wang a, Bolin Wang a,b, Yuxue Yue a, Chunxiao Jin a, Jinyue Lu a, Zheng Fang a, \\ Xiangxue Pang a, Feng Feng a, Lingling Guo a, Zhiyan Pan b, Xiaonian Li a,\# \\ a Industrial Catalysis Institute of Zhejiang University of Technology, Hangzhou 310014, Zhejiang, China \\ b Department of Environmental Engineering, Zhejiang University of Technology, Hangzhou 310014, Zhejiang, China
}

\section{A R T I C L E I N F O}

\section{Article history:}

Received 21 March 2020

Accepted 10 May 2020

Published 5 February 2021

\section{Keywords:}

Acetylene hydrochlorination

Electron density

Hydrogen chloride activation

Stabilization mechanism

Gold-based supported ionic liquid

phase catalyst

\begin{abstract}
A B S T R A C T
The activation of $\mathrm{HCl}$ by cationic $\mathrm{Au}$ in the presence of $\mathrm{C}_{2} \mathrm{H}_{2}$ is important for the construction of active $\mathrm{Au}$ sites and in acetylene hydrochlorination. Here, we report a strategy for activating $\mathrm{HCl}$ by the Au-based supported ionic liquid phase (Au-SILP) technology with the $\left[\mathrm{N}(\mathrm{CN})_{2}-\right]$ anion. This strategy enables $\mathrm{HCl}$ to accept electrons from $\left[\mathrm{N}(\mathrm{CN})_{2}{ }^{-}\right]$anions in $\mathrm{Au}-\left[\mathrm{N}(\mathrm{CN})_{2}{ }^{-}\right]$complexes rather than from pure $[\mathrm{Bmim}]\left[\mathrm{N}(\mathrm{CN})_{2}\right]$, leading to notable improvement in both the reaction path and the stability of the catalyst without changing the reaction triggered by acetylene adsorption. Furthermore, the induction period of the Au-SILP catalyst was shown to be absent in the reaction process due to the high $\mathrm{Au}(\mathrm{III})$ content in the $\mathrm{Au}(\mathrm{III}) / \mathrm{Au}(\mathrm{I})$ site and the high substrate diffusion rate in the ionic liquid layer. This work provides a facile method to improve the stability of Au-based catalysts for acetylene hydrochlorination.
\end{abstract}

(C) 2021, Dalian Institute of Chemical Physics, Chinese Academy of Sciences. Published by Elsevier B.V. All rights reserved.

\section{Introduction}

Polyvinyl chloride (PVC) is widely used in various fields due to its outstanding properties, such as excellent mechanical and electrical properties and easy processing [1-8]. Currently, PVC is mainly produced using vinyl chloride monomer (VCM) through ethylene oxychlorination or acetylene hydrochlorination [9-15]. Compared with ethylene oxychlorination, acetylene hydrochlorination has the advantages of a single reaction step and low operating costs, but the reaction has to be catalyzed by mercury chloride $\left(\mathrm{HgCl}_{2}\right)$ with activated carbon (AC)
[16-20]. However, the $\mathrm{HgCl}_{2}$ catalyst may cause environmental pollution because of its high volatility and toxicity [17-24]. Thus, intensive efforts have been devoted to developing Hg-free catalysts for acetylene hydrochlorination [25-35].

Since the seminal work of Hutchings in 1972 [1], Au catalysts have attracted intensive research interest, and the $\mathrm{AuCl}_{3}$ catalyst has been shown to have high activity for acetylene hydrochlorination, with the $\mathrm{Au}(\mathrm{III}) / \mathrm{Au}(\mathrm{I})$ pair acting as the active redox site [36,37]. Even today, the Au-catalyzed hydrochlorination reaction is still considered as the most promising non-Hg hydrochlorination technology [38-42]. However, $\mathrm{Au}$

\footnotetext{
* Corresponding author. Tel: +86-571-88871656; E-mail: jiazhao@zjut.edu.cn

\# Corresponding author. Tel: +86-571-88320002; E-mail: xnli@zjut.edu.cn

Financial support by the National Natural Science Foundation of China (21606199) and Science and Technology Department of Zhejiang Province (LGG20B060004) is gratefully acknowledged.

DOI: 10.1016/S1872-2067(20)63617-8 | http://www.sciencedirect.com/science/journal/18722067 | Chin. J. Catal., Vol. 42, No. 2, February 2021
} 
catalysts suffer from several intrinsic defects: (i) reduction of cationic $\mathrm{Au}$ species ( $\mathrm{Au}(\mathrm{III})$ and $\mathrm{Au}(\mathrm{I})$ ) to metallic $\mathrm{Au}(0)$ species in the presence of an electron-rich substrate (such as $\mathrm{C}_{2} \mathrm{H}_{2}$ ); (ii) dependence of activity on the dispersion of $\mathrm{Au}$ (particularly, atomic dispersion of $\mathrm{Au}$ in carbon), which will require exact control of particle size and cause poor reproducibility of catalyst performance; and (iii) aggregation of $\mathrm{Au}(0)$ species or $\mathrm{Au}$ nanoparticles (NPs) because of the high surface energy, leading to the deactivation of the catalyst. Previous studies have shown that the oxidation of $\mathrm{Au}$ can be protected and regenerated through on-line or off-line treatments in the presence of inorganic moieties, i.e., $\mathrm{CN}_{2}-, \mathrm{S}_{2} \mathrm{O}_{3}{ }^{2-}, \mathrm{SCN}^{-}, \mathrm{I}^{-}$, or $\mathrm{Br}^{-}$[43-45]. Therein, Hutchings et al. revealed excellent catalytic performance and obtained significant insights on the active site through the protective effect of $\mathrm{S}_{2} \mathrm{O}_{3}{ }^{2-}$; furthermore, they have successfully carried out a pilot-scale evaluation of the functional protected $\mathrm{Au} / \mathrm{C}$-based catalyst in China. Moreover, halohydrocarbons (C-X, X=Cl, I, Br) were extensively used in the redispersion of sintered $\mathrm{Au} / \mathrm{AC}$ catalysts via the regeneration of oxidative $\mathrm{Au}$ species $[44,45]$, which revealed a strategy and further indicated the particular importance of inorganic moieties in protecting high-valance Au species. Currently, the stability challenge has been mainly addressed by the (i) adaptation of chelating soft donor atoms and (ii) stably anchored catalytic sites, suggesting the necessity for research on alternative stabilization methods to reduce the progressive deactivation.

Supported ionic liquid phase (SILP) catalysts, a special variant of supported liquid phase catalysts, feature the advantages of heterogeneous and molecular catalysis due to the immobilization of the catalytically active components in the ionic liquid (IL) layer [46-53]. Previous reports have shown the successful application of IL-immobilized catalysts in reactions such as hydroformylation of olefins [54,55], hydrogenation [56,57], gas-shift reaction [58,59], and hydrosilylation $[60,61]$. In our previous work, the Au(III) complex supported on AC promoted with the 1-propyl-3-methylimidazolium chloride IL ([Prmim] $[\mathrm{Cl}]$ ) was tested in the gas-phase acetylene hydrochlorination [62]. The prepared Au-IL/AC catalyst showed high activity and selectivity (turnover frequency (TOF) $=79.2 \mathrm{~h}^{-1}$, and selectivity for VCM formation > 99.8\%); however, deactivation after prolonged use still occurred due to the reduction of cationic $\mathrm{Au}$ species to metallic $\mathrm{Au}(0)$. While $\mathrm{CuCl}_{2}$ modification can self-regenerate the deactivated $\mathrm{Au}-\mathrm{IL} / \mathrm{AC}$ catalyst via a redox mechanism [18], the addition of a $\mathrm{Cu}$ promoter may cause the problem of noble metal recycling. To solve these problems, we need to further explore the chemistry of high-valent late transition metals and fabricate more stable, efficient, low-cost, and environment-friendly catalysts for acetylene hydrochlorination.

Compared with acetylene activation, the activation of hydrogen chloride $(\mathrm{HCl})$ has not received enough attention in the construction of stable Au-based catalysts for acetylene hydrochlorination. Despite the lowest unoccupied molecular orbital (LUMO) for $\sigma^{*} \mathrm{H}-\mathrm{Cl}$ [63], $\mathrm{HCl}$ is generally activated by oxidation rather than reduction over catalytic metals, particularly for late transition metal cations. Recent research has indicated that $\mathrm{HCl}$ adsorption may proceed via a dissociative mechanism on
$\mathrm{N}$-doped carbon materials [73], leading to the formation of a new $\mathrm{N}-\mathrm{H}$ bond, as well as either the adsorption of $\mathrm{Cl}$ ion on the cavity of $\mathrm{N}$-doped carbon or its motion on the surface. Inspired by this, we developed $\left[\mathrm{N}(\mathrm{CN})_{2}{ }^{-}\right]$as functional inorganic moieties for the synthesis of a coordinated $[\mathrm{Bmim}]\left[\mathrm{N}(\mathrm{CN})_{2}\right]$ IL to stabilize high-valance Au species and investigate the catalytic performance of the Au-N(CN) $2 / \mathrm{AC}$ catalyst (Scheme 1) in acetylene hydrochlorination. The experimental and theoretical calculation results indicate that the dissociation of $\mathrm{HCl}$ on $\left[\mathrm{N}(\mathrm{CN})_{2}-\right]$ to form free $\mathrm{Cl}^{-}$appears to be the main contributor to the stabilization of cationic Au species. These results provide some clues as to the design of stable high-valent Au-based catalysts for acetylene hydrochlorination.

\section{Experimental procedures and theoretical investigation}

\subsection{Catalyst preparation}

The Au-based SILP catalysts were prepared using the wet impregnation method. Briefly, $\mathrm{HAuCl}_{4} \cdot x \mathrm{H}_{2} \mathrm{O}$ (Sigma-Aldrich) was dissolved in an $\mathrm{HCl}$ acid solution, followed by the addition of certain amounts of ILs. After stirring for $1 \mathrm{~h}$, the mixed solution was dropwise added to AC under stirring. The AC (Norit ROX 0.8) was pre-treated with aqua regia to remove impurities (such as residual metal ions). Subsequently, the pre-prepared wet catalysts were maintained at $60^{\circ} \mathrm{C}$ for $12 \mathrm{~h}$, followed by drying at $110{ }^{\circ} \mathrm{C}$ for another $12 \mathrm{~h}$. Finally, the dried products were collected as catalysts and termed as $\mathrm{Au}-\mathrm{X} / \mathrm{AC}$, where $\mathrm{X}$ represents the ILs used. For example, $\mathrm{Au}-\mathrm{Cl} / \mathrm{AC}$ and $\mathrm{Au}-\mathrm{N}(\mathrm{CN})_{2} / \mathrm{AC}$ catalysts were prepared with 1-butyl-3-methylimidazolium chloride ([Bmim][Cl]) and 1-butyl-3-methylimidazolium dicyanamide ([Bmim] $\left.\left[\mathrm{N}(\mathrm{CN})_{2}\right]\right)$ (Lanzhou Greenchem. ILS, LICP. CAS.), respectively. The $\mathrm{Au}$ content in all the catalysts was fixed at $0.1 \mathrm{wt} \%$, and the content of ILs was maintained at $10 \mathrm{wt} \%$ unless otherwise stated.

\subsection{Catalyst characterization}

A Micromeritics ASAP 2020 instrument was used to investigate the physical structure of the catalysts in terms of pore structure and specific surface. Energy dispersive X-ray (EDX)

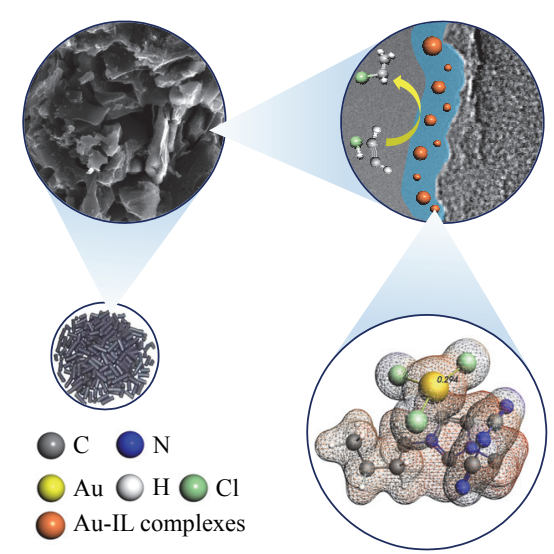

Scheme 1. Schematic representation of the $\mathrm{Au}-\mathrm{N}(\mathrm{CN})_{2} / \mathrm{AC}$ catalyst. The image is not drawn to scale. 
spectroscopy was used to analyze the distribution and atomic structure of the active components on a Tecnai G2 F30 S-Twin. The aberration-corrected scanning transmission electron microscopy (AC-STEM) was used for direct analysis of the distribution of isolated single Au atoms. The X-ray diffraction (XRD) spectra were recorded on a PANalytical-X'Pert PRO instrument. The valance state of the Au sites was investigated by X-ray photoelectron spectroscopy (XPS) using a Kratos AXIS Ultra DLD spectrometer. Synchrotron-radiated X-ray absorption fine structure (XAFS) measurement is known as a powerful tool for investigating the electronic structure and coordination environment of catalysts. In this study, the relevant XAFS measurements were carried out at the Shanghai Synchrotron Radiation Facility (SSRF). Herein, the X-ray absorption near-edge structure (XANES) was recorded to analyze the orbital occupancy and charge state of the $\mathrm{Au}$ atoms in the investigated catalysts. The extended X-ray absorption fine structure (EXAFS) in the prepared catalysts was evaluated via Fourier-transform (FT) analysis to determine the coordination structure in terms of coordination atoms, number, and distance between the $\mathrm{Au}$ atoms and neighboring atoms.

\subsection{Catalyst tests}

The activity and stability of the as-prepared Au-based catalysts were evaluated in a typical fixed-bed reactor (Figure S1). First, a certain amount of the catalyst was loaded in the reactor, followed by sweeping with $\mathrm{N}_{2}$ gas at $120^{\circ} \mathrm{C}$ for at least $0.5 \mathrm{~h}$ to remove impurities, such as water and air. Thereafter, a $\mathrm{C}_{2} \mathrm{H}_{2}$ and $\mathrm{HCl}$ mixed gas $\left(V\left(\mathrm{C}_{2} \mathrm{H}_{2}\right): V(\mathrm{HCl})=1: 1.2\right)$ was added, which was controlled using a mass flowmeter at a gas hourly space velocity (GHSV, $\mathrm{C}_{2} \mathrm{H}_{2}$ ) of $1000 \mathrm{~h}^{-1}$. The mixed gas obtained from the reactor outlet was washed by a $\mathrm{NaOH}$ solution and then analyzed by gas chromatography using a Porapak $\mathrm{N}$ packed column $(6 \mathrm{ft} \times 1 / 800$ stainless steel). The peak areas were normalized to investigate the gas-phase products. Given the complete absorption of $\mathrm{HCl}$, the volume of the reaction system can be considered constant for the calculations. The amount of $\mathrm{C}_{2} \mathrm{H}_{4} \mathrm{Cl}_{2}$ and chlorinated oligomeric by-products was determined by introducing the reactor outflow into an $\mathrm{N}$-methylpyrrolidone solution and analyzing the obtained N-methylpyrrolidone solution using a Waters GCT Premier chromatograph equipped with an HP-5 capillary column. The conversion was defined as the amount of $\mathrm{C}_{2} \mathrm{H}_{2}$ reacted divided by the amount of $\mathrm{C}_{2} \mathrm{H}_{2}$ introduced. The selectivity toward VCM was calculated as the amount of VCM formed divided by the amount of $\mathrm{C}_{2} \mathrm{H}_{2}$ reacted, and the carbon balance based on these products was nearly $100 \%$. Adopting the calculation method in the literature [36], we define the productivity calculated in this work as follows:

Productivity = Amount of VCM produced/Amount of $\mathrm{Au}$ ( $\mathrm{kg}_{\mathrm{vCM}} \mathrm{kg}_{\mathrm{Au}}{ }^{-1} \mathrm{~min}^{-1}$ )

\subsection{Computational details}

All energies and structures were calculated using the density functional theory (DFT) under periodic boundary conditions as implemented in the Amsterdam density functional band-structure (ADF-BAND) package, coupled with the Perdew-Burke-Ernzerhof (PBE) functional and scalar relativistic corrections. A DZP basis set was used for the determination of valence orbitals, and a TZP basis set was used for the determination of Pd. The self-consistent field was converged to a value of $10^{-5}$ in Hartree energy units. Gradients were converged to 0.001 Hartree/Å. All other measurements were performed under the default setting.

\section{Results and discussion}

\subsection{Catalyst characterization}

A homogeneous solution containing the IL and the Au precursor was obtained by dissolving the $\mathrm{Au}$ precursor, $\mathrm{HAuCl}_{4} \cdot 3 \mathrm{H}_{2} \mathrm{O}$, separately in the $[\mathrm{Bmim}]\left[\mathrm{N}(\mathrm{CN})_{2}\right]$ (Figure S2a) and [Bmim] [Cl] (Figure S2b) ILs, followed by the preparation of the Au-SILP catalysts of $\mathrm{Au}-\mathrm{N}(\mathrm{CN})_{2} / \mathrm{AC}$ and $\mathrm{Au}-\mathrm{Cl} / \mathrm{AC}$ using the conventional impregnation method [1] and vacuum removal of the added deionized water. The physical structures of AC before and after catalyst preparation were investigated using the Brunauer-Emmett-Teller (BET) method, and the textural parameters are shown in Table 1 . The surface area and the pore volume were $722 \mathrm{~m}^{2} \mathrm{~g}^{-1}$ and $0.39 \mathrm{~cm}^{3} \mathrm{~g}^{-1}$ (Figures 1a and S3) for $\mathrm{Au}-\mathrm{N}(\mathrm{CN})_{2} / \mathrm{AC}$, and $737 \mathrm{~m}^{2} \mathrm{~g}^{-1}$ and $0.40 \mathrm{~cm}^{3} \mathrm{~g}^{-1}$ for $\mathrm{Au}-\mathrm{Cl} / \mathrm{AC}$, respectively. The decreased surface area and pore volume of $\mathrm{AC}$ (Table 1 ) were ascribed to the $[\mathrm{Bmim}]\left[\mathrm{N}(\mathrm{CN})_{2}\right]$ and $[\mathrm{Bmim}][\mathrm{Cl}]$ IL layers inside the pore. Similar results have been reported in the literature [18,46,62]. Previously, we demonstrated that the immobilization of ILs on the AC support is attributed to the high free p-electron density of carbon supports, leading to the formation of more $\mathrm{CH}-\pi$ bonds with $\mathrm{H}$ atoms at the C2 position of the acidic cation [64]. Thermogravimetric (TG) analysis showed that the supported $[\mathrm{Bmim}]\left[\mathrm{N}(\mathrm{CN})_{2}\right]$ and $[\mathrm{Bmim}][\mathrm{Cl}]$ ILs were remarkably stable and remained undecomposed at temperatures below $240{ }^{\circ} \mathrm{C}$ (Figure S4), suggesting the stability of the ILs under the reaction conditions of acetylene hydrochlorination.

The morphology and the dispersion of Au-SILP catalysts were investigated, and Figure $1 \mathrm{~b}$ shows the STEM image and elemental mapping of the $\mathrm{Au}-\mathrm{N}(\mathrm{CN})_{2} / \mathrm{AC}$ catalyst. The STEM data revealed that most of the Au species were homogeneously and highly dispersed on the carrier surface, as evidenced by the absence of crystalline NPs. Elemental mapping analysis indicated a homogeneous distribution of $\mathrm{N}, \mathrm{Au}$, and $\mathrm{Cl}$ atoms (Figure S5). STEM morphology and the elemental mapping of $\mathrm{Au}-\mathrm{Cl} / \mathrm{AC}$ confirmed the immobilization of homogeneously

\section{Table 1}

Textural properties of the AC support and Au-SILP catalysts.

\begin{tabular}{lccc}
\hline Sample & $S_{\text {BET }}\left(\mathrm{m}^{2} \mathrm{~g}^{-1}\right)^{\mathrm{a}}$ & Volume $\left(\mathrm{cm}^{3} \mathrm{~g}^{-1}\right)^{\mathrm{b}}$ & Diameter $(\mathrm{nm})^{\mathrm{c}}$ \\
\hline $\mathrm{Au}-\mathrm{N}(\mathrm{CN})_{2} / \mathrm{AC}$ & 722 & 0.39 & 2.01 \\
$\mathrm{Au}-\mathrm{Cl} / \mathrm{AC}$ & 737 & 0.40 & 2.04 \\
$\mathrm{AC}$ & 1135 & 0.64 & 2.20 \\
\hline
\end{tabular}

a Measured using the Brunauer-Emmett-Teller (BET) method; ${ }^{\mathrm{b}}$ calculated based on the adsorbed $\mathrm{N}_{2}$ volume; ${ }^{c}$ determined by the Barrett-Joyner-Halenda (BJH) method. 



Fig. 1. Characterizations of the Au-N(CN)$)_{2}$ /AC catalyst. (a) $\mathrm{N}_{2}$ gas adsorption/desorption isotherms; (b) STEM image and elemental mapping analysis; (c) XRD patterns; (d) representative HAADF-STEM image and (e) Au $4 f$ XPS spectra.

dispersed Au species and the IL phase on the AC support. Inductively coupled plasma mass spectrometry (ICP-MS) analysis verified the consistency of the Au metal loading with the nominal amount of metal impregnated onto the support (Table S1). No reflections associated with the metallic $\mathrm{Au}$ species were observed in the XRD spectra of $\mathrm{Au}-\mathrm{N}(\mathrm{CN})_{2} / \mathrm{AC}$ (Figure 1c) and $\mathrm{Au}-\mathrm{Cl} / \mathrm{AC}$ (Figure S6), implying the existence of $\mathrm{Au}$ on the $\mathrm{AC}$ surface either in an amorphous state or with a particle size below the XRD detection limit [65-67]. Based on this speculation, we characterized the HAADF-STEM micrographs of the $\mathrm{Au}-\mathrm{N}(\mathrm{CN})_{2} / \mathrm{AC}$ catalyst (Figure $1 \mathrm{~d}$ ) and detected predominantly isolated $\mathrm{Au}$ sites on the AC surface. For $\mathrm{Au}-\mathrm{Cl} / \mathrm{AC}$, a considerably large fraction of isolated $\mathrm{Au}$ sites coupled with a relatively minor component of Au clusters were observed on the AC support (Figure S7a). The obtained results suggested that single-atom Au catalysts can be easily synthesized via confining metal into the IL layer. Additionally, the Au valence states in $\mathrm{Au}-\mathrm{N}(\mathrm{CN})_{2} / \mathrm{AC}$ and $\mathrm{Au}-\mathrm{Cl} / \mathrm{AC}$ were detected by XPS analysis. $\mathrm{Au}-\mathrm{N}(\mathrm{CN})_{2} / \mathrm{AC}$ showed two Au states characterized by $\mathrm{Au} 4 \mathrm{f}_{7 / 2}$ binding energies (BEs) of 86.7-86.9 and 85.1-85.5 eV [68,69], which can be attributed to the high-valent $\mathrm{Au}(\mathrm{III})$ and $\mathrm{Au}(\mathrm{I})$ species, respectively (Figure 1e). Furthermore, the peaks at 84.0-84.2 eV [70,71] were assigned as the metallic $\mathrm{Au}(0)$ in $\mathrm{Au}-\mathrm{Cl} / \mathrm{AC}$ (Figure S7b), which was in accord with our previous work [18,62]. The XPS data were consistent with the HAADF-STEM micrographs of Au-N(CN) $/$ AC (Figure 1d) and $\mathrm{Au}-\mathrm{Cl} / \mathrm{AC}$ (Figure $\mathrm{S} 7 \mathrm{a})$. The existence of $\mathrm{Au}(0)$ with a small size in the $\mathrm{Au}-\mathrm{Cl} / \mathrm{AC}$ catalyst may be attributed to the reduction of $\mathrm{Au}(\mathrm{III})$ by the AC support [72] or the beam-induced photoreaction of $\mathrm{Au}(\mathrm{III})$ salts [36,62]. XPS fitting parameters for various samples are listed in Table S2. The high proportion of cationic $\mathrm{Au}$ species in the $\mathrm{Au}-\mathrm{N}(\mathrm{CN})_{2} / \mathrm{AC}$ catalyst suggested that the $[\mathrm{Bmim}]\left[\mathrm{N}(\mathrm{CN})_{2}\right]$ IL can stabilize $\mathrm{Au}(\mathrm{III})$ species more effectively than the $[\mathrm{Bmim}][\mathrm{Cl}] \mathrm{IL}$.

X-ray absorption spectroscopy (XAS) was employed to evaluate the electronic structure and coordination environment of the $\mathrm{Au}-\mathrm{N}(\mathrm{CN})_{2} / \mathrm{AC}$ and $\mathrm{Au}-\mathrm{Cl} / \mathrm{AC}$ catalysts by comparing the white-line intensity values (the magnitude of the electronic transition from the $2 p_{3 / 2}$ core-level state to a vacant $5 d$ state) and other spectral features with those of the reference samples (Au foil, $\mathrm{KAuCl}_{4}$, and $\left(\mathrm{PPh}_{3}\right) \mathrm{AuCH}_{3}$ ). Table 2 shows the EXAFS fitting parameters at the Au L3-edge for various samples. The white-line intensity values of the Au standards were 0.76, 1.14, and 0.81 for $\mathrm{Au}$ foil $(\mathrm{Au}(0)), \mathrm{KAuCl}_{4}(\mathrm{Au}(\mathrm{III})$ ), and $\left(\mathrm{PPh}_{3}\right) \mathrm{AuCH}_{3}(\mathrm{Au}(\mathrm{I}))$, respectively, which are consistent with the measured values in literature $[36,37,73]$. The typical normalized white-line intensity values of $\mathrm{Au}-\mathrm{N}(\mathrm{CN})_{2} / \mathrm{AC}$ and $\mathrm{Au}-\mathrm{Cl} / \mathrm{AC}$ were 1.04 and 0.85 (Figure 2), which were closer to the cationic $\mathrm{Au}(\mathrm{III})$ and $\mathrm{Au}(\mathrm{I})$ standards, respectively. To the best of our knowledge, the intensity of the white line increases as the oxidation state increases [36,37,73]. Therefore, the measured results indicated the presence of cationic Au species in the form of mixed $\mathrm{Au}(\mathrm{III}) / \mathrm{Au}(\mathrm{I})$ on the $\mathrm{Au}-\mathrm{N}(\mathrm{CN})_{2} / \mathrm{AC}$ and $\mathrm{Au}-\mathrm{Cl} / \mathrm{AC}$ catalysts. In addition, more $\mathrm{Au}(\mathrm{III})$ species were generated on $\mathrm{Au}-\mathrm{N}(\mathrm{CN})_{2} / \mathrm{AC}$ than on $\mathrm{Au}-\mathrm{Cl} / \mathrm{AC}$ due to the former's higher white-line intensity values. This difference in $\mathrm{Au}$ species on the surface is probably caused by the coordination structure of cationic Au species. Therefore, the local structure evolution around $\mathrm{Au}$ atoms was studied by FT-EXAFS. In Figure 2b, we can observe the presence of $\mathrm{Au}-\mathrm{Cl}$ entities at about $2.27 \AA$ and $\mathrm{Au}-\mathrm{N}$ entities at about $3.22 \AA$ in the $\mathrm{Au}-\mathrm{N}(\mathrm{CN})_{2} / \mathrm{AC}$ sample with average coordination numbers (CNs) of 1.4 and 5.3 for $\mathrm{Au}-\mathrm{Cl}$ and $\mathrm{Au}-\mathrm{N}$, respectively, in contrast to the $\mathrm{Au}-\mathrm{Cl}$ entities $(\mathrm{CN}=$ 3.0) at about $2.27 \AA$ and $\mathrm{Au}$-Au entities $(\mathrm{CN}=0.5)$ at about 2.86 $\AA$ for the $\mathrm{Au}-\mathrm{Cl} / \mathrm{AC}$ catalyst. These results demonstrate that cationic Au species can be well stabilized during the synthesis 
Table 2

EXAFS fitting parameters at the $\mathrm{Au} L 3$-edge for $\mathrm{Au}-\mathrm{N}(\mathrm{CN})_{2} / \mathrm{AC}$ and $\mathrm{Au}-\mathrm{Cl} / \mathrm{AC}$ catalysts.

\begin{tabular}{|c|c|c|c|c|c|c|}
\hline Sample & Scattering path & $\mathrm{CN}^{\mathrm{a}}$ & $R(\AA)^{\mathrm{b}}$ & $\sigma^{2}\left(\AA^{2}\right)^{\mathrm{c}}$ & $\Delta E_{0}(\mathrm{eV})^{\mathrm{d}}$ & $R$ factor \\
\hline Au foil & $\mathrm{Au}-\mathrm{Au}$ & 12 & 2.86 & 0.0079 & 3.9 & 0.004 \\
\hline $\mathrm{KAuCl}_{4}$ & $\mathrm{Au}-\mathrm{Cl}$ & 3.9 & 2.27 & 0.0024 & 9.2 & 0.018 \\
\hline \multirow{2}{*}{$\left(\mathrm{PPh}_{3}\right) \mathrm{AuCH}_{3}$} & $\mathrm{Au}-\mathrm{P}$ & 1.7 & 2.28 & \multirow{2}{*}{0.0032} & \multirow{2}{*}{2.4} & \multirow{2}{*}{0.008} \\
\hline & $\mathrm{Au}-\mathrm{C}$ & 1.0 & 2.05 & & & \\
\hline \multirow{2}{*}{$\mathrm{Au}-\mathrm{Cl} / \mathrm{AC}$} & $\mathrm{Au}-\mathrm{Cl}$ & 3.0 & 2.27 & \multirow{2}{*}{0.0012} & \multirow{2}{*}{8.3} & \multirow{2}{*}{0.014} \\
\hline & $\mathrm{Au}-\mathrm{Au}$ & 0.5 & 2.86 & & & \\
\hline \multirow{2}{*}{$\mathrm{Au}-\mathrm{N}(\mathrm{CN})_{2} / \mathrm{AC}$} & $\mathrm{Au}-\mathrm{Cl}$ & 1.4 & 2.27 & \multirow{2}{*}{0.0013} & \multirow{2}{*}{2.0} & \multirow{2}{*}{0.019} \\
\hline & $\mathrm{Au}-\mathrm{N}$ & 5.3 & 3.22 & & & \\
\hline
\end{tabular}

${ }^{\mathrm{a}} \mathrm{CN}$ : coordination number; ${ }^{\mathrm{b}} R$ : bond distance; ${ }^{\mathrm{c}} \sigma^{2}$ : Debye-Waller factor; ${ }^{\mathrm{d}} \Delta E_{0}$ : the inner potential correction. $R$ factor: goodness of fit. $S_{0}{ }^{2}$ was set to 0.829 by fixing $\mathrm{CN}$ as the known crystallographic value according to the experimental EXAFS fit of Au foil reference. The error bounds that characterize the structural parameters obtained by EXAFS spectroscopy were estimated as $\mathrm{CN} \pm 20 \% ; R \pm 1 \% ; \sigma^{2} \pm 20 \% ; \Delta E_{0} \pm 20 \%$.
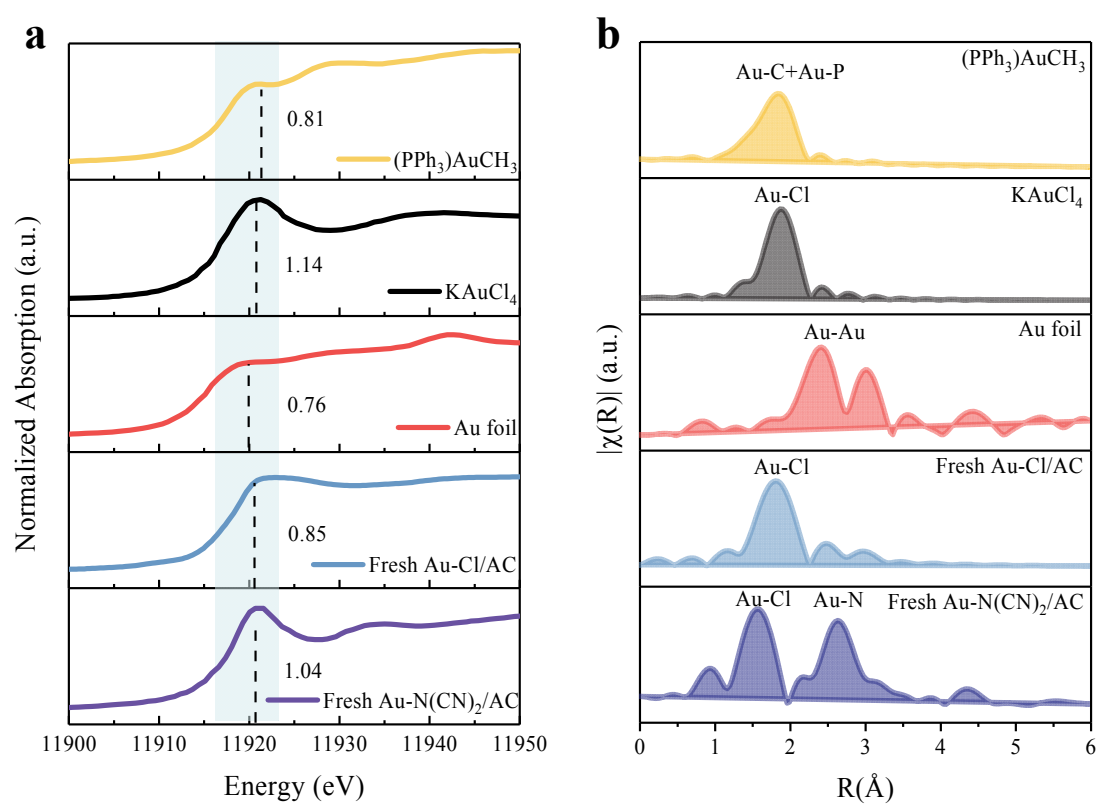

Fig. 2. The edge-normalized XANES spectra at the $\mathrm{Au} L 3$-edge for the $\mathrm{Au}-\mathrm{N}(\mathrm{CN})_{2} / \mathrm{AC}$ and $\mathrm{Au}-\mathrm{Cl} / \mathrm{AC}$ catalysts and reference Au samples. (a) White line intensity and (b) R-space.

of catalysts in the presence of $\mathrm{Au}-\mathrm{N}$ entities for $\mathrm{Au}-\mathrm{N}(\mathrm{CN})_{2} / \mathrm{AC}$.

\subsection{Catalytic performance}

The promotion effect of ILs on the Au-based catalysts over acetylene hydrochlorination was evaluated using $[\mathrm{Bmim}]\left[\mathrm{N}(\mathrm{CN})_{2}\right]$ and $[\mathrm{Bmim}][\mathrm{Cl}]$, and Figure 3 and Figure S8a show the evaluated results of the $\mathrm{Au}-\mathrm{N}(\mathrm{CN})_{2} / \mathrm{AC}$ and $\mathrm{Au}-\mathrm{Cl} / \mathrm{AC}$ catalysts. Specifically, the catalytic performance of the two catalysts was studied first by evaluating their optimal reaction temperature in the range of $140-220^{\circ} \mathrm{C}$ (Figure S8a), with each point determined by an isolated test to eliminate the interference of catalyst deactivation. The reaction temperature of 180 ${ }^{\circ} \mathrm{C}$ was defined as the optimal reaction temperature because the highest VCM productivity for both $\mathrm{Au}-\mathrm{N}(\mathrm{CN})_{2} / \mathrm{AC}$ and $\mathrm{Au}-\mathrm{Cl} / \mathrm{AC}$ was achieved at this temperature (Figures S8a and S8b). After temperature evaluation, the catalytic ability of the two Au-SILP catalysts was investigated by stability tests on a laboratory scale. In Figure $3 \mathrm{a}$, the $\mathrm{Au}-\mathrm{N}(\mathrm{CN})_{2} / \mathrm{AC}$ catalyst is shown to have a higher VCM productivity and durability within $100 \mathrm{~h}$ on stream than the Au-Cl/AC catalyst, indicating that the
[Bmim $]\left[\mathrm{N}(\mathrm{CN})_{2}\right]$ IL can provide a suitable microenvironment for Au species during the reaction.

The catalytic ability of the Au-N(CN) $2 / A C$ catalyst was further explored by analyzing the relationship among the GHSV, $\mathrm{Au}$ loading, and VCM productivity ( $\mathrm{kg}_{\mathrm{VCM}} \mathrm{kg}_{\mathrm{Au}}{ }^{-1} \mathrm{~min}^{-1}$ ) (Figure 3b). In the three-dimensional graph, it is shown that even at a relatively high GHSV and a low metal loading, the $\mathrm{Au}-\mathrm{N}(\mathrm{CN})_{2} / \mathrm{AC}$ catalyst still exhibited superior catalytic activity. A turning point in productivity at an Au loading of $0.25 \mathrm{wt} \%$ is observed under a variety of GHSV values. Meanwhile, the $\mathrm{Au}-\mathrm{N}(\mathrm{CN})_{2} / \mathrm{AC}$ catalyst is not sensitive to the change in the GHSV, as shown by a productivity increase of only $\sim 20 \mathrm{kgVCM}$ $\mathrm{kg}_{\mathrm{Au}^{-1}} \mathrm{~min}^{-1}$ with the increase of GHSV from $500 \mathrm{~h}^{-1}$ to $2000 \mathrm{~h}^{-1}$ at the $\mathrm{Au}$ loading of $0.1 \mathrm{wt} \%$; in addition, a relatively small changing trend of the VCM productivity is observed with a further increase of the Au loading. As is shown in Figure S9b, the catalytic activity of the $\mathrm{Au}-\mathrm{N}(\mathrm{CN})_{2} / \mathrm{AC}$ catalyst increased with the increase in the Au loading, and no noticeable decrease in activity for all the catalysts was observed within $10 \mathrm{~h}$ at $180{ }^{\circ} \mathrm{C}$ and $1000 \mathrm{~h}^{-1}$, indicating that the stabilization method in this study is also effective for the ultra-low Au content of $0.01 \mathrm{wt} \%$. 

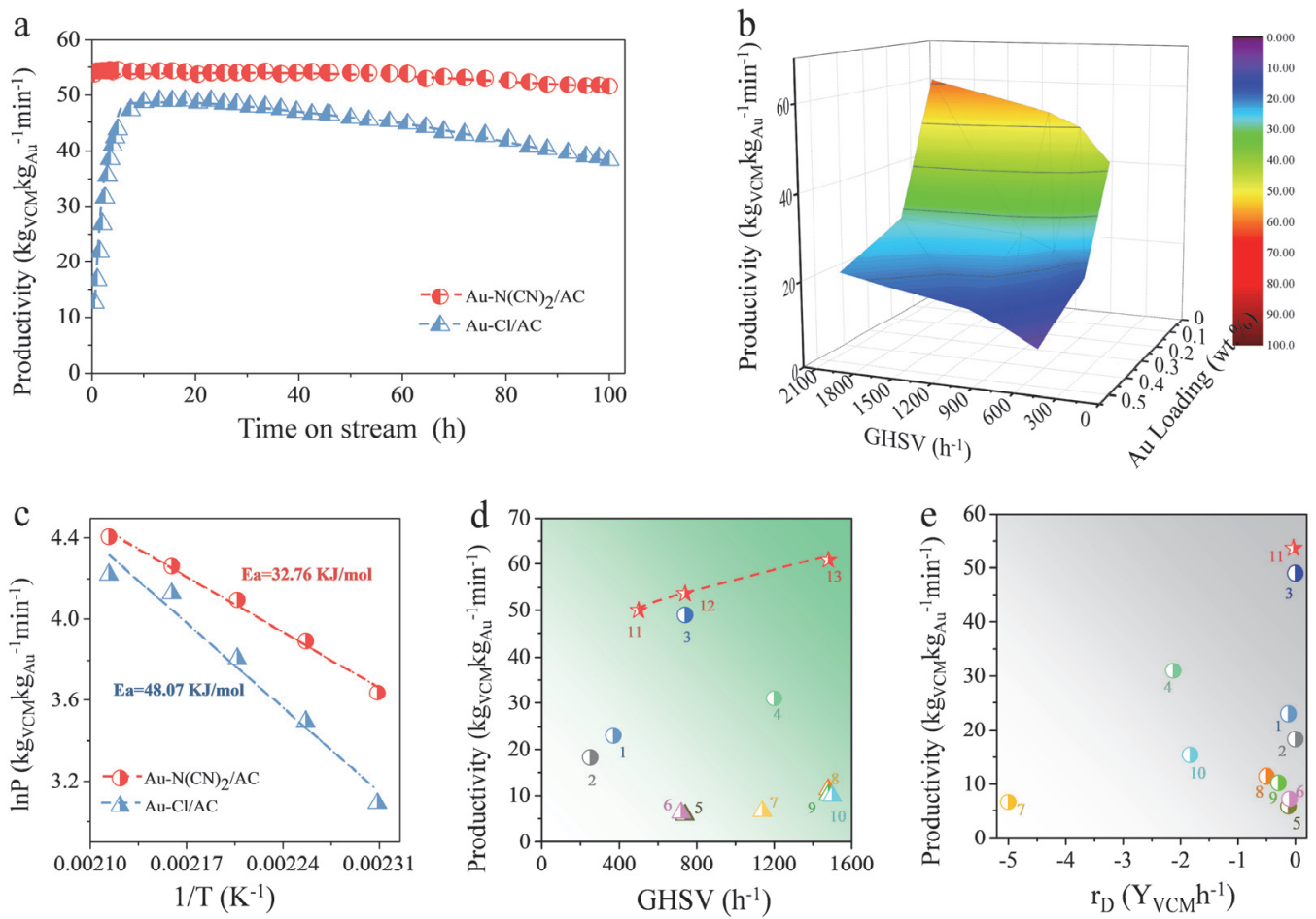

Fig. 3. VCM productivity as a function of (a) time on stream, h, and at GHSV $\left(\mathrm{C}_{2} \mathrm{H}_{2}\right)=1000 \mathrm{~h}^{-1}$; (b) VCM productivity versus the GHSV and Au loading for the investigated $\mathrm{Au}-\mathrm{N}(\mathrm{CN})_{2} / \mathrm{AC}$; (c) apparent activation energies of the $\mathrm{Au}-\mathrm{Cl} / \mathrm{AC}$ and $\mathrm{Au}-\mathrm{N}(\mathrm{CN})_{2} / \mathrm{AC}$ catalysts; (d) VCM productivity of $\mathrm{Au}-\mathrm{N}(\mathrm{CN})_{2} / \mathrm{AC}$ and other $\mathrm{Au}$-based catalysts reported in literature. Numbers 11-13 indicate the productivity of the Au-N(CN) $/ \mathrm{AC}$ catalyst at different $\operatorname{GHSV}\left(\mathrm{C}_{2} \mathrm{H}_{2}\right.$ ) values; (e) VCM productivity as a function of the deactivation rate for various samples.

As the catalytic activity originates from the promotion of $[\mathrm{Bmim}]\left[\mathrm{N}(\mathrm{CN})_{2}\right]$, the activation energies of the $\mathrm{Au}-\mathrm{N}(\mathrm{CN})_{2} / \mathrm{AC}$ and $\mathrm{Au}-\mathrm{Cl} / \mathrm{AC}$ catalysts were calculated for further analysis of the properties of this reaction. [Bmim] $\left[\mathrm{N}(\mathrm{CN})_{2}\right]$ in the Au-based catalyst has a lower activation energy $\left(E_{\mathrm{a}}=32.76 \mathrm{~kJ} \mathrm{~mol}^{-1}\right)$ than [Bmim] $[\mathrm{Cl}]\left(E_{\mathrm{a}}=48.07 \mathrm{~kJ} \mathrm{~mol}^{-1}\right)$, indicating that the acetylene hydrochlorination reaction catalyzed by the $\mathrm{Au}-\mathrm{N}(\mathrm{CN})_{2} / \mathrm{AC}$ catalyst tends to be more easily triggered under the same reaction conditions. The relatively low activation energy of $\mathrm{Au}-\mathrm{N}(\mathrm{CN})_{2} / \mathrm{AC}$ may be responsible for the relatively high catalytic activity of the Au-N(CN)2/AC catalyst (Figure 3c). Additionally, a comparison of Au catalysts reported in the literature $[1,17,18,24,33,41,62,70,73,74]$ revealed that the $\mathrm{Au}-\mathrm{N}(\mathrm{CN})_{2} / \mathrm{AC}$ catalyst shows considerable VCM productivity under different hydrochlorination conditions (Figure 3d), which can rival the performance of state-of-the-art Au-based catalysts at similar temperatures, although a relatively high GHSV for the $\mathrm{Au}-\mathrm{N}(\mathrm{CN})_{2} / \mathrm{AC}$ catalyst was obtained in our reaction. Moreover, the deactivation rates calculated in this work and other references (Table S3) suggest the excellent stability of the $\mathrm{Au}-\mathrm{N}(\mathrm{CN})_{2} / \mathrm{AC}$ catalyst. Furthermore, the correlation of VCM production versus the deactivation rate of the catalysts was established and is shown in Figure 3e, which reveals that the $\mathrm{Au}-\mathrm{N}(\mathrm{CN})_{2} / \mathrm{AC}$ catalyst has the highest VCM productivity but a negligible deactivation rate. These results demonstrate that the introduced [Bmim] $\left[\mathrm{N}(\mathrm{CN})_{2}\right]$ contributes to the outstanding activity and durability of the $\mathrm{Au}-(\mathrm{CN})_{2} / \mathrm{AC}$ catalyst for acetylene hydrochlorination.

\subsection{Induction phenomenon and catalytic activity}

Figure 3 shows the distinct catalytic behaviors (induction phenomenon and catalytic activity) of the two investigated catalysts. The reaction with the $\mathrm{Au}-\mathrm{Cl} / \mathrm{AC}$ catalyst presented a long induction period of $10 \mathrm{~h}$ (Figure 3a), with the VCM productivity being maintained at about $50 \mathrm{kgvcm} \mathrm{kgAu}^{-1} \mathrm{~min}^{-1}$ for $12 \mathrm{~h}$, followed by a decline. In contrast, $\mathrm{Au}-\mathrm{N}(\mathrm{CN})_{2} / \mathrm{AC}$ exhibited good catalytic stability within $100 \mathrm{~h}$, with no evident induction period being observed. This distinction indicated their potential difference in the active species and/or interphase mass transfer. Hutchings mentioned that the induction period for Au-based catalysts was typically $3 \mathrm{~h}$, which was allotted to the redox coupling of the $\mathrm{Au}(\mathrm{III}) / \mathrm{Au}(\mathrm{I})$ sites in the $\mathrm{Au}$-catalyzed hydrochlorination of acetylene, including the oxidation of $\mathrm{Au}(\mathrm{I})$ sites to predominant $\mathrm{Au}(\mathrm{III})$ sites during the first $20 \mathrm{~min}$ under the reaction conditions, followed by the reduction to $\mathrm{Au}(\mathrm{I})$ sites during the subsequent $160 \mathrm{~min}$ [36]. This result indicates that the induction period necessary for this reaction can be shortened by increasing the $\mathrm{Au}(\mathrm{III})$ content in the $\mathrm{Au}(\mathrm{III}) / \mathrm{Au}(\mathrm{I})$ couple, which was verified by the higher number of $\mathrm{Au}$ (III) species in $\mathrm{Au}-\mathrm{N}(\mathrm{CN})_{2} / \mathrm{AC}$ than in $\mathrm{Au}-\mathrm{Cl} / \mathrm{AC}$ in the XAS results (Figure 2a). However, it should be noted that the induction period of $10 \mathrm{~h}$ for the $\mathrm{Au}-\mathrm{Cl} / \mathrm{AC}$ catalyst in this work is overly high and evidently different from the induction period of 2-5 h reported for the classical Au-catalyzed acetylene hydrochlorination (Table S4), suggesting the redox coupling process of $\mathrm{Au}(\mathrm{III}) / \mathrm{Au}(\mathrm{I})$ is unlikely to be the only deter- 
minant of the induction period. As the thin film dissolved Au-complex supported on AC is established on the $\mathrm{Au}-\mathrm{N}(\mathrm{CN})_{2} / \mathrm{AC}$ and $\mathrm{Au}-\mathrm{Cl} / \mathrm{AC}$ catalysts, the dissolution and diffusion of reactants in this IL film should not be neglected, particularly in the initial stage of this reaction.

The interfacial structure and property between an IL and the reactants were studied first due to their intrinsic importance to understand the dissolution and diffusion behavior of $\mathrm{C}_{2} \mathrm{H}_{2}$ and $\mathrm{HCl}$ in ILs. $\mathrm{C}_{2} \mathrm{H}_{2}$ is known to weakly bind to polar organic molecules containing a heteroatom through interactions between $\mathrm{X} \cdot \cdots \mathrm{H}-\mathrm{C}$ (acetylene) (hydrogen bond) and $\mathrm{X}-\mathrm{H}$...C(acetylene) (where $\mathrm{X}$ can be a proton acceptor, such as 0 , N , or halogen atoms $[46,60,75]$. This means that $\mathrm{C}_{2} \mathrm{H}_{2}$ can be hydrogen-bonded to the heteroatom or heteroatoms of the anion of ILs. For the selected ILs in this work, the occurrence of the hydrogen bond interaction between the $\mathrm{H}$ atom of $\mathrm{C}_{2} \mathrm{H}_{2}$ and the proton acceptor of the IL anion (Figures $4 \mathrm{~b}, 4 \mathrm{e}$ ) suggests that the dissolution and diffusion behaviors of $\mathrm{C}_{2} \mathrm{H}_{2}$ in the ILs are affected by this hydrogen-bond interaction. The distinct activation mechanism of $\mathrm{HCl}$ was determined for $\mathrm{Cl}^{-}$and $\mathrm{N}(\mathrm{CN})_{2}$-based ILs, with $\mathrm{HCl}$ being more inclined to form hydrogen bonds with the cation in the [Bmim] [Cl] IL (Figure 4c) and anion in $[\mathrm{Bmim}]\left[\mathrm{N}(\mathrm{CN})_{2}\right]$ (Figure $4 \mathrm{f}$ ). Evidently, the reactants tend to dissolve in the IL film in the form of hydrogen bonds and are activated at the same time.

Additionally, the solubilities of $\mathrm{C}_{2} \mathrm{H}_{2}$ and $\mathrm{HCl}$ over $[\mathrm{Bmim}]\left[\mathrm{N}(\mathrm{CN})_{2}\right]$ and $[\mathrm{Bmim}][\mathrm{Cl}]$ were evaluated using the
COSMO-RS method. As shown in Figures 4g-h, the solubilities of $\mathrm{C}_{2} \mathrm{H}_{2}$ and $\mathrm{HCl}$ decreased with increasing temperature. The solubility values (herein expressed as the mole fraction) of $\mathrm{C}_{2} \mathrm{H}_{2}$ and $\mathrm{HCl}$ at the reaction temperature of $180{ }^{\circ} \mathrm{C}$ were 0.007 and 0.068 for $\mathrm{Au}-\mathrm{N}(\mathrm{CN})_{2} / \mathrm{AC}$, and 0.004 and 0.029 for $\mathrm{Au}-\mathrm{Cl} / \mathrm{AC}$, respectively. The solubilities of $\mathrm{C}_{2} \mathrm{H}_{2}$ and $\mathrm{HCl}$ were slightly higher in $[\mathrm{Bmim}][\mathrm{Cl}]$ than in $[\mathrm{Bmim}]\left[\mathrm{N}(\mathrm{CN})_{2}\right]$. We have proven above that $\mathrm{C}_{2} \mathrm{H}_{2}$ and $\mathrm{HCl}$ undergoes predominantly chemical dissolution in ILs, which can be affected by hydrogen-bond interaction between the substrates $\left(\mathrm{C}_{2} \mathrm{H}_{2}\right.$ and $\left.\mathrm{HCl}\right)$ and the basic atoms of the ILs. Therefore, the higher solubilities of $\mathrm{C}_{2} \mathrm{H}_{2}$ and $\mathrm{HCl}$ in $[\mathrm{Bmim}][\mathrm{Cl}]$ than in $[\mathrm{Bmim}]\left[\mathrm{N}(\mathrm{CN})_{2}\right]$ can be ascribed to the stronger hydrogen-bond basicity in $\left.\mathrm{Cl}^{-}\right](0.95)$ than in $\left[\mathrm{N}(\mathrm{CN})_{2} 2^{-}\right](0.60)$ [75]. Meanwhile, the higher solubility of both the substrate molecules in $[\mathrm{Bmim}][\mathrm{Cl}]$ than in $[\mathrm{Bmim}]\left[\mathrm{N}(\mathrm{CN})_{2}\right]$ suggests that solubility is probably not the main factor responsible for the long induction period and low catalytic activity of $\mathrm{Au}-\mathrm{Cl} / \mathrm{AC}$ relative to $\mathrm{Au}-\mathrm{N}(\mathrm{CN})_{2} / \mathrm{AC}$.

As a catalytic reaction is a process of continuous collision of reaction molecules, the Wilke-Chang correlation was used to estimate the diffusion coefficients of $\mathrm{C}_{2} \mathrm{H}_{2}$ and $\mathrm{HCl}$, which were $9.07 \times 10^{-9} \mathrm{~m}^{2} \mathrm{~s}^{-1}$ and $5.02 \times 10^{-9} \mathrm{~m}^{2} \mathrm{~s}^{-1}$ in [Bmim][Cl], and $1.14 \times 10^{-8} \mathrm{~m}^{2} \mathrm{~s}^{-1}$ and $9.57 \times 10^{-9} \mathrm{~m}^{2} \mathrm{~s}^{-1}$ in $[\mathrm{Bmim}]\left[\mathrm{N}(\mathrm{CN})_{2}\right]$ (Figure 4i), respectively. This difference in the diffusion coefficient can be attributed to the difference in the IL anions induced by identical cations. The analysis of the calculated results revealed an apparently higher diffusion rate of substrates in a

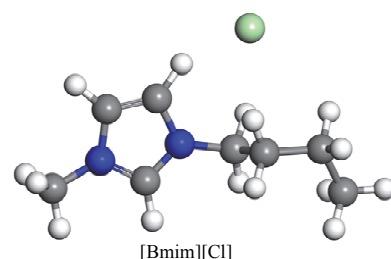

d
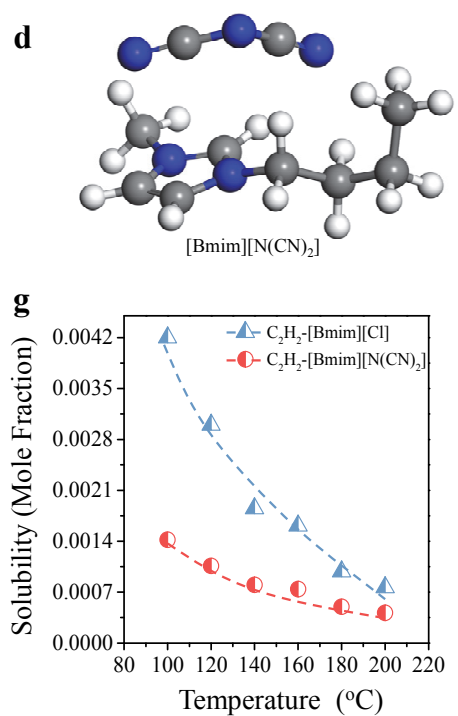

b
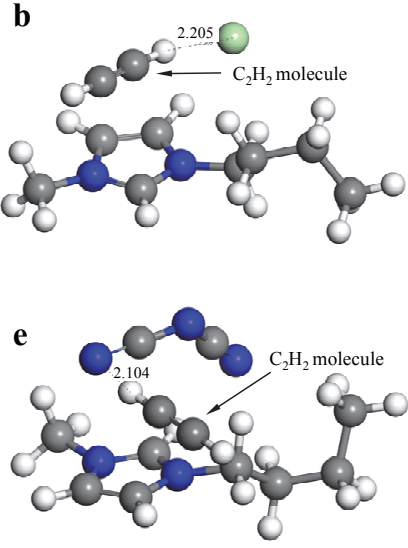

h

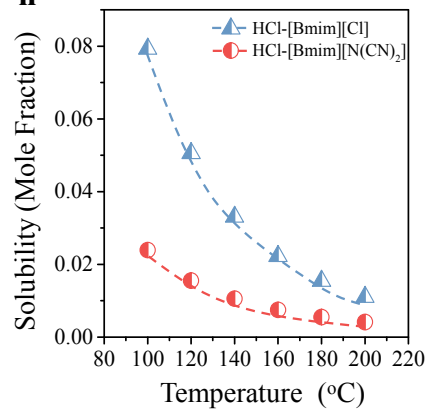

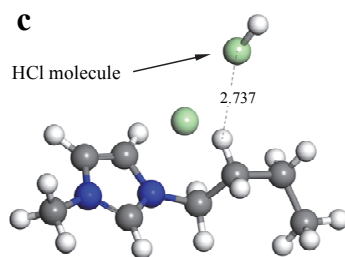

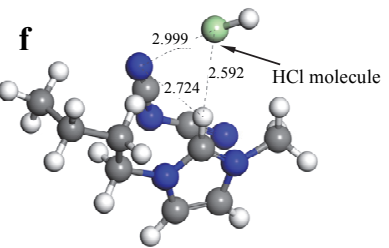

i

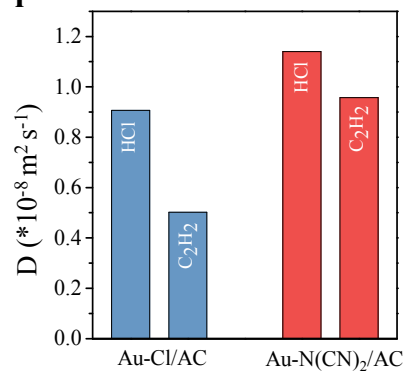

Fig. 4. Optimized structures of (a) $[\mathrm{Bmim}][\mathrm{Cl}]$, (b) $\mathrm{C}_{2} \mathrm{H}_{2}-[\mathrm{Bmim}][\mathrm{Cl}]$, (c) $\mathrm{HCl}-[\mathrm{Bmim}][\mathrm{Cl}]$, (d) $[\mathrm{Bmim}]\left[\mathrm{N}(\mathrm{CN})_{2}\right]$, (e) $\mathrm{C}_{2} \mathrm{H}_{2}-[\mathrm{Bmim}]\left[\mathrm{N}(\mathrm{CN})_{2}\right]$, and (f) $\mathrm{HCl}-[\mathrm{Bmim}]\left[\mathrm{N}(\mathrm{CN})_{2}\right]$. The dotted lines represent the possible modes of interaction, with interatomic distances in angstroms. The solubilities of $(\mathrm{g})$ $\mathrm{C}_{2} \mathrm{H}_{2}$ and $(\mathrm{h}) \mathrm{HCl}$ in the investigated [Bmim] $[\mathrm{Cl}]$ and [Bmim] $\left[\mathrm{N}(\mathrm{CN})_{2}\right]$ ILs at different temperatures; (i) diffusion coefficients for $\mathrm{C}_{2} \mathrm{H}_{2}$ and $\mathrm{HCl}$ in $[\mathrm{Bmim}][\mathrm{Cl}]$ and $[\mathrm{Bmim}]\left[\mathrm{N}(\mathrm{CN})_{2}\right]$. Color code: $\mathrm{H}$, white; $\mathrm{C}$, gray; $\mathrm{N}$, blue; $\mathrm{Cl}$, light green. 
$[\mathrm{Bmim}]\left[\mathrm{N}(\mathrm{CN})_{2}\right]$ than in $[\mathrm{Bmim}][\mathrm{Cl}]$. Similar results had also been reported by Dai et al [76]. Apart from the initial content of $\mathrm{Au}(\mathrm{III})$ in the $\mathrm{Au}(\mathrm{III}) / \mathrm{Au}(\mathrm{I})$ sites, the lower diffusion rate of substrates in $[\mathrm{Bmim}][\mathrm{Cl}]$ also contributed to the long induction period of the $\mathrm{Au}-\mathrm{Cl} / \mathrm{AC}$ catalyst. Therefore, the induction period of the catalyst in the reaction process can be eliminated through the strategy of ensuring a high Au(III) content in the $\mathrm{Au}(\mathrm{III}) / \mathrm{Au}(\mathrm{I})$ sites, in addition to a sufficiently high substrate diffusion rate in the IL layer.

\subsection{Proposed mechanism}

In this study, the stabilization mechanism of the cationic $\mathrm{Au}$ species in the steady-state process was also studied. As the deactivation of the Au-based catalysts in acetylene hydrochlorination is considered as the main result of cationic $\mathrm{Au}$ reduction by $\mathrm{C}_{2} \mathrm{H}_{2}$, the remarkably higher catalytic stability of $\mathrm{Au}-\mathrm{N}(\mathrm{CN})_{2} / \mathrm{AC}$ than that of $\mathrm{Au}-\mathrm{Cl} / \mathrm{AC}$ suggests that the $[\mathrm{Bmim}]\left[\mathrm{N}(\mathrm{CN})_{2}\right]$-stabilized cationic $\mathrm{Au}$ species are stable enough to resist the deactivation of the metallic Au reduced by the strongly reducing $\mathrm{C}_{2} \mathrm{H}_{2}$. The characterization results of the spent catalysts indicated that carbon deposition and $\mathrm{Au}$ leaching were not the main causes of catalyst deactivation (Table 3). XPS analysis confirmed the presence of metallic $\mathrm{Au}(0)$ species in the spent $\mathrm{Au}-\mathrm{Cl} / \mathrm{AC}$ sample (Figure $5 \mathrm{c}$ ), but not in the spent $\mathrm{Au}-\mathrm{N}(\mathrm{CN})_{2} / \mathrm{AC}$ catalyst (Figure $5 \mathrm{~d}$ ), demonstrating that the cationic Au species are highly stable when $\mathrm{Au}-\mathrm{Cl}$ is substituted by $\mathrm{Au}-\mathrm{N}$. The agglomeration of atomically dispersed $\mathrm{Au}$ into large clusters was also determined from the HAADF-STEM images of the spent $\mathrm{Au}-\mathrm{Cl} / \mathrm{AC}$ catalyst (Figure 5a). For $\mathrm{Au}-\mathrm{N}(\mathrm{CN})_{2} / \mathrm{AC}$, the atomically dispersed $\mathrm{Au}$ was still maintained over the surface of the spent $\mathrm{Au}-\mathrm{N}(\mathrm{CN})_{2} / \mathrm{AC}$ catalyst (Figure 5b), further verifying that the $\mathrm{Au}(\mathrm{III})$ is stabilized by [Bmim] $\left[\mathrm{N}(\mathrm{CN})_{2}\right]$. To the best of our knowledge, $\mathrm{Au}-\mathrm{Cl}$ sites or $\mathrm{AuCl}_{3}$, are labile and easy to dissociate/disproportionate in the process of catalyst synthesis and evaluation [41]. The stability constant of the Au-N coordination is several orders of magnitude higher than that of the $\mathrm{Au}-\mathrm{Cl}$ coordination [41], which inhibits the migration of $\mathrm{Au}$ atoms during the preparation of the catalyst. Accordingly, the strong interaction between the $\mathrm{Au}-\mathrm{N}$ contributions stabilized and inhibited the reduction of the cationic Au species in the process of catalytic preparation and reaction.

The electronic properties of the cationic Au species stabilized by $[\mathrm{Bmim}]\left[\mathrm{N}(\mathrm{CN})_{2}\right]$ and $[\mathrm{Bmim}][\mathrm{Cl}]$ ILs were further investigated by Hirshfeld charge analysis. In accordance with the literature [41], we focused on $\mathrm{AuCl}_{3}$ in the following mechanistic study due to the role of cationic $\mathrm{Au}(\mathrm{III})$ in the selection of an

Table 3

Porous structure and metal content of the spent Au-based catalysts.

\begin{tabular}{lccc}
\hline Sample & $\begin{array}{c}S_{\text {BET }} \\
\left(\mathrm{m}^{2} \mathrm{~g}^{-1}\right)^{\mathrm{a}}\end{array}$ & $\begin{array}{c}\text { Volume } \\
\left(\mathrm{cm}^{3} \mathrm{~g}^{-1}\right)^{\mathrm{b}}\end{array}$ & $\begin{array}{c}\text { Au content } \\
(\mathrm{wt} \%)^{\mathrm{c}}\end{array}$ \\
\hline Spent $\mathrm{Au}-\mathrm{N}(\mathrm{CN})_{2} / \mathrm{AC}$ & 695 & 0.38 & 0.09 \\
Spent $\mathrm{Au}-\mathrm{Cl} / \mathrm{AC}$ & 787 & 0.37 & 0.11 \\
\hline
\end{tabular}

a Measured using the Brunauer-Emmett-Teller (BET) method; ${ }^{\mathrm{b}}$ calculated based on the adsorbed $\mathrm{N}_{2}$ volume; c determined by ICP-MS analysis.
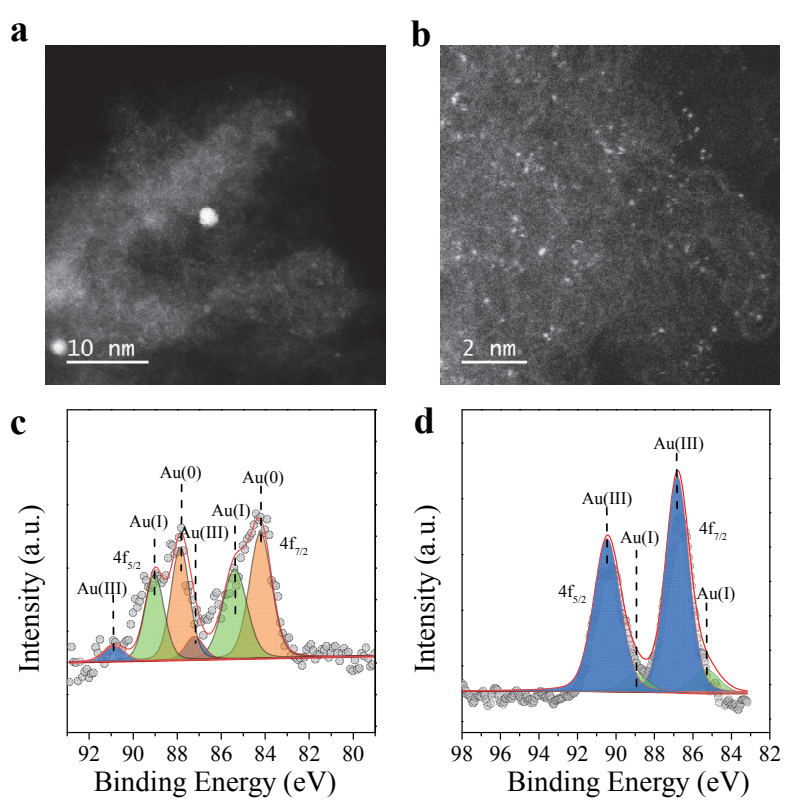

Fig. 5. Characterizations of the spent $(\mathrm{a}, \mathrm{c}) \mathrm{Au}-\mathrm{Cl} / \mathrm{AC}$ and $(\mathrm{b}, \mathrm{d})$ Au-N(CN)2/AC catalysts. (a,b) TEM images; (c,d) XPS results.

Au source for the catalyst synthesis and induction period of the reaction process. Additionally, the core role of $\mathrm{Au}(\mathrm{III})$ in the catalytic behavior is also shown by its dominance in the XPS and EXAFS spectra of $\mathrm{Au}-\mathrm{N}(\mathrm{CN})_{2} / \mathrm{AC}$ and $\mathrm{Au}-\mathrm{Cl} / \mathrm{AC}$. The Hirshfeld charge of the $\mathrm{Au}$ atom in $[\mathrm{Bmim}]\left[\mathrm{N}(\mathrm{CN})_{2}\right]$ was lower (0.294 e) than that $(0.334 \mathrm{e})$ of [Bmim] [Cl], which were close to the values of $\mathrm{Au}(\mathrm{I})$ and $\mathrm{Au}(\mathrm{III})$ with charges of 0.204 e and 0.356 e when modeled as $\mathrm{AuCl}$ and $\mathrm{AuCl}_{3}$ (Table S6), respectively. In the $\mathrm{Au} / \mathrm{AC}$ catalyst, $\mathrm{Au}(\mathrm{I})$ can be generated via the thermal decomposition of $\mathrm{Au}(\mathrm{III})$ species [36,37]. Therefore, the improved stability of the Au species in $[\mathrm{Bmim}]\left[\mathrm{N}(\mathrm{CN})_{2}\right]$ of the $\mathrm{Au}-\mathrm{N}(\mathrm{CN})_{2} / \mathrm{AC}$ catalyst can be attributed to the $\mathrm{Au}(\mathrm{I})$ characteristic of the $\left[\mathrm{N}(\mathrm{CN})_{2}-\right]$-stabilized cationic $\mathrm{Au}(\mathrm{III})$. As is shown in Figure S9, the average Hirshfeld charge on $\mathrm{N}$ atoms in the $\left[\mathrm{N}(\mathrm{CN})_{2}-\right]$ anion of $\mathrm{AuCl}_{3}-[\mathrm{Bmim}]\left[\mathrm{N}(\mathrm{CN})_{2}\right]$ complexes is $-0.175 \mathrm{e}$, which is much lower than that in the pure $[\mathrm{Bmim}]\left[\mathrm{N}(\mathrm{CN})_{2}\right]$ IL $(-0.274 \mathrm{e})$, suggesting that some of the electrons of the $\mathrm{N}$ atoms in $\left[\mathrm{N}(\mathrm{CN})_{2}\right]$ transferred to $\mathrm{Au}$ atoms, since the Hirshfeld charge on Au was decreased from 0.356 to 0.294 e. Meanwhile, when the catalyst adsorbs $\mathrm{C}_{2} \mathrm{H}_{2}$ and $\mathrm{HCl}$ molecules in the reaction process, the Hirshfeld charges on the $\mathrm{N}$ and $\mathrm{Au}$ atoms do not change significantly $(\mathrm{Au}<0.034 \mathrm{e}$, $\mathrm{N}<0.006$ e), indicating the stabilization effect of $\left[\mathrm{N}(\mathrm{CN})_{2}\right]$ anions on the electron structure of the Au species, which cannot be achieved by $\left[\mathrm{Cl}^{-}\right]$anions, as shown in Figure $6 \mathrm{~b}(\mathrm{Au}<0.099 \mathrm{e})$.

The regulatory effect of the electronic structure of the $\mathrm{Au}$ atoms on the activation of substrates was studied by thermal programmed desorption mass spectroscopy (TPD-MS). Previous studies assigned the atomic masses of 26 and 36 to $\mathrm{C}_{2} \mathrm{H}_{2}$ and $\mathrm{HCl}[73,77]$, respectively. The peaks at $155^{\circ} \mathrm{C}$ and $174{ }^{\circ} \mathrm{C}$ (Figure S10a) represent the desorption profiles of $\mathrm{C}_{2} \mathrm{H}_{2}$ from the $\mathrm{Au}-\mathrm{N}(\mathrm{CN})_{2} / \mathrm{AC}$ and $\mathrm{Au}-\mathrm{Cl} / \mathrm{AC}$ catalysts. In general, the desorption temperatures in the TPD profiles reflect the binding 
a

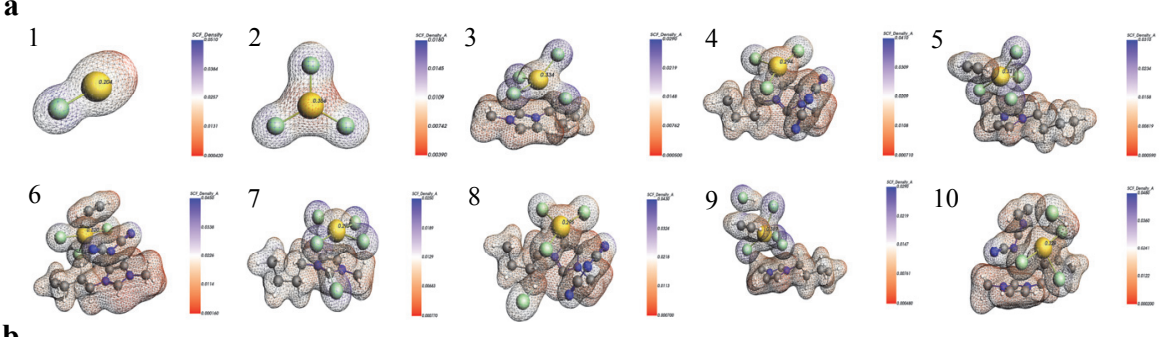

b

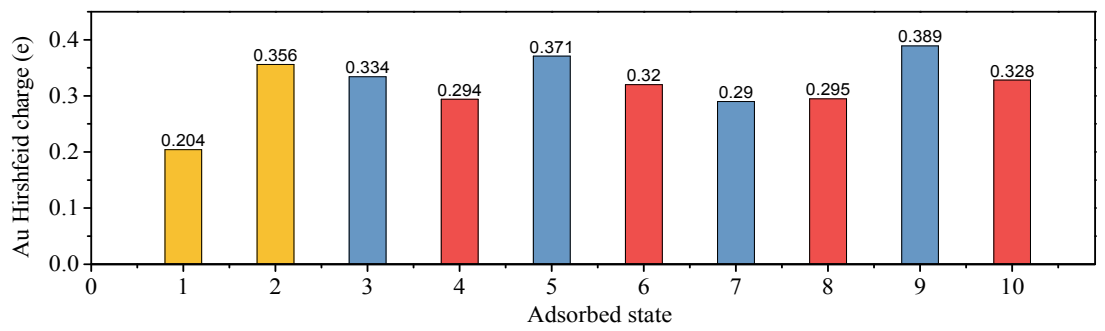

Fig. 6. (a) Electron density and (b) the Hirshfeld charge of the Au atoms in various Au states.

strength of the adsorbed sites on the catalyst surface, and the peak area correlates with the number of adsorbed sites [46-48]. Accordingly, the adsorption of $\mathrm{C}_{2} \mathrm{H}_{2}$ on $\mathrm{Au}-\mathrm{N}(\mathrm{CN})_{2} / \mathrm{AC}$ was inhibited due to the smaller peak area and lower desorption temperature of $\mathrm{C}_{2} \mathrm{H}_{2}$ in $\mathrm{Au}-\mathrm{N}(\mathrm{CN})_{2} / \mathrm{AC}$ than in $\mathrm{Au}-\mathrm{Cl} / \mathrm{AC}$. Furthermore, the selected catalysts were studied by HCl-TPD analysis. As shown in Figure S10b, the desorption content of $\mathrm{HCl}$ on $\mathrm{Au}-\mathrm{N}(\mathrm{CN})_{2} / \mathrm{AC}$ was lower than that of $\mathrm{Au}-\mathrm{Cl} / \mathrm{AC}$, due to the small difference in the desorption temperature, which is in contrast to the similar adsorption of $\mathrm{HCl}$ on both catalysts. The $\mathrm{C}_{2} \mathrm{H}_{2}$ and $\mathrm{HCl}$ desorption contents from TPD analysis were consistent with the solubility values from the theoretical calculation.

The above TPD results indicated that the involvement of the ligand, $\left[\mathrm{N}(\mathrm{CN})_{2}^{-}\right]$, in the formation of the Au- $\mathrm{N}$ contribution through $\mathrm{Au}$ coordination enables the resulting structure to notably inhibit the adsorption of $\mathrm{C}_{2} \mathrm{H}_{2}$, thereby stabilizing the cationic Au species. The activation of $\mathrm{C}_{2} \mathrm{H}_{2}$ on the $\mathrm{Au}(\mathrm{III})$ sites of $\mathrm{Au}-\mathrm{N}(\mathrm{CN})_{2} / \mathrm{AC}$ and $\mathrm{Au}-\mathrm{Cl} / \mathrm{AC}$ catalysts was further elucidated by the Hirshfeld charge analysis. Table $\mathrm{S} 6$ shows the calculated charge distributions before and after $\mathrm{C}_{2} \mathrm{H}_{2}$ adsorption on $\mathrm{Au}-\mathrm{N}(\mathrm{CN})_{2} / \mathrm{AC}$ and $\mathrm{Au}-\mathrm{Cl} / \mathrm{AC}$. A more positive charge was detected in the $\mathrm{Au}$ centers of $\mathrm{Au}-\mathrm{N}(\mathrm{CN})_{2} / \mathrm{AC}$ and $\mathrm{Au}-\mathrm{Cl} / \mathrm{AC}$ after $\mathrm{C}_{2} \mathrm{H}_{2}$ adsorption, indicating the flow of electrons from the $\mathrm{Au}$ center to the $\mathrm{C}_{2} \mathrm{H}_{2}$ substrate and suggesting the strong adsorption of $\mathrm{C}_{2} \mathrm{H}_{2}$. It is worth noting that the electron flow was more significant in $\mathrm{Au}-\mathrm{Cl} / \mathrm{AC}$ than in $\mathrm{Au}-\mathrm{N}(\mathrm{CN})_{2} / \mathrm{AC}$ due to the generation of 0.037 e and 0.026 e Hirshfeld charges in the adsorption process, indicating the higher probability of $\mathrm{C}_{2} \mathrm{H}_{2}$ to be adsorbed at the $\mathrm{Au}$ center stabilized by [ $\left.\mathrm{Cl}^{-}\right]$ligands than that by $\left[\mathrm{N}(\mathrm{CN})_{2}{ }^{-}\right]$ligands. In other words, the adsorption of $\mathrm{C}_{2} \mathrm{H}_{2}$ was weakened on $\left[\mathrm{N}(\mathrm{CN})_{2}{ }^{-}\right]$-stabilized $\mathrm{Au}$ atoms, which was consistent with the solubility and TPD measurements. When $\mathrm{HCl}$ was adsorbed, the Hirshfeld charge values of the $\mathrm{Au}$ atoms were changed from the initial $0.294 \mathrm{e}$ and 0.334 e to $0.295 \mathrm{e}$ and 0.290 e for $\mathrm{Au}-\mathrm{N}(\mathrm{CN})_{2} / \mathrm{AC}$ and $\mathrm{Au}-\mathrm{Cl} / \mathrm{AC}$ catalysts, respectively, with -0.001 and 0.044 electrons being transferred from the $\mathrm{HCl}$ atom to the $\mathrm{Au}$ atom of $\mathrm{Au}-\mathrm{N}(\mathrm{CN})_{2} / \mathrm{AC}$ and $\mathrm{Au}-\mathrm{Cl} / \mathrm{AC}$.
Strong $\mathrm{HCl}$ adsorption was observed on the $\left[\mathrm{Cl}^{-}\right]$-stabilized $\mathrm{Au}$ atoms, in contrast to the slight interaction detected on the $\left[\mathrm{N}(\mathrm{CN})_{2} 2^{-}\right.$-stabilized Au atoms.

To gain more insights into the adsorption properties of the substrates, we calculated the adsorption energies of $\mathrm{C}_{2} \mathrm{H}_{2}$ and $\mathrm{HCl}$ on $\mathrm{Au}-\mathrm{N}(\mathrm{CN})_{2} / \mathrm{AC}$ and $\mathrm{Au}-\mathrm{Cl} / \mathrm{AC}$ as -75.54 and $-85.48 \mathrm{~kJ}$ $\mathrm{mol}^{-1}$, suggesting that the $\left[\mathrm{N}(\mathrm{CN})_{2}-\right]$-stabilized $\mathrm{Au}$ atoms weakened the strong adsorption of $\mathrm{C}_{2} \mathrm{H}_{2}$, which was consistent with the results obtained by Hirshfeld charge and TPD analyses. For the $\mathrm{HCl}$ adsorbed states, the adsorption energies were $-23.23 \mathrm{~kJ} \mathrm{~mol}-1$ on $\mathrm{Au}-\mathrm{N}(\mathrm{CN})_{2} / \mathrm{AC}$ and $-80.02 \mathrm{~kJ} \mathrm{~mol}^{-1}$ on $\mathrm{Au}-\mathrm{Cl} / \mathrm{AC}$, which were also consistent with the results of Hirshfeld charge analysis. It should be noted that almost no electron is transferred between [N(CN)2-]-stabilized $\mathrm{Au}$ atoms and $\mathrm{HCl}$ for $\mathrm{Au}-\mathrm{N}(\mathrm{CN})_{2} / \mathrm{AC}$, and the adsorption energy is probably due to the adsorption of the acidic $\mathrm{HCl}$ on the basic $\left[\mathrm{N}(\mathrm{CN})_{2}-\right]$ anion in $\mathrm{Au}-\mathrm{N}(\mathrm{CN})_{2} / \mathrm{AC}$.

The different adsorption properties of the $\mathrm{C}_{2} \mathrm{H}_{2}$ and $\mathrm{HCl}$ molecules on $\mathrm{Au}-\mathrm{N}(\mathrm{CN})_{2} / \mathrm{AC}$ and $\mathrm{Au}-\mathrm{Cl} / \mathrm{AC}$ induced the variation of the reaction paths in acetylene hydrochlorination. The electron cloud density of the basic structure is shown in Figures $\mathrm{S} 11-\mathrm{S} 13$. Due to the lower adsorption energy of $\mathrm{C}_{2} \mathrm{H}_{2}$ than that of $\mathrm{HCl}$, the reactions of $\mathrm{Au}-\mathrm{N}(\mathrm{CN})_{2} / \mathrm{AC}$ and $\mathrm{Au}-\mathrm{Cl} / \mathrm{AC}$ were likely to be triggered by the adsorption and activation of $\mathrm{C}_{2} \mathrm{H}_{2}$. The reaction pathway analysis did show that the coordination of $\mathrm{C}_{2} \mathrm{H}_{2}$ in the absence of $\mathrm{HCl}$ results in site blocking through the formation of this stable metal cycling structure (Figure 7), which was consistent with the inactivation observed under $\mathrm{C}_{2} \mathrm{H}_{2}$ exposure [1-7]. Based on DFT calculations, the proposed catalytic cycles of $\mathrm{Au}-\mathrm{N}(\mathrm{CN})_{2} / \mathrm{AC}$ and $\mathrm{Au}-\mathrm{Cl} / \mathrm{AC}$-catalyzed acetylene hydrochlorinations consisted of eight elementary steps: the coordination of $\mathrm{AuCl}_{3}$ on selected ILs (step 1), the adsorption of $\mathrm{C}_{2} \mathrm{H}_{2}$ (step 2) and $\mathrm{HCl}$ (step 3), the formation of the transition state (step 4), the surface reaction (steps 5 and 6), and the desorption of vinyl chloride (steps 7 and 8). For the $\mathrm{Au}-\mathrm{N}(\mathrm{CN})_{2} / \mathrm{AC}$ catalyst, $\mathrm{C}_{2} \mathrm{H}_{2}$ was first adsorbed to the $\mathrm{Au}$ atoms of $\mathrm{AuCl}_{3}$ (step 2), after which it interacted with $\mathrm{HCl}$ to form the more stable $\mathrm{HCl}-\mathrm{C}_{2} \mathrm{H}_{2}$ sites (step 3). The adsorption energy 


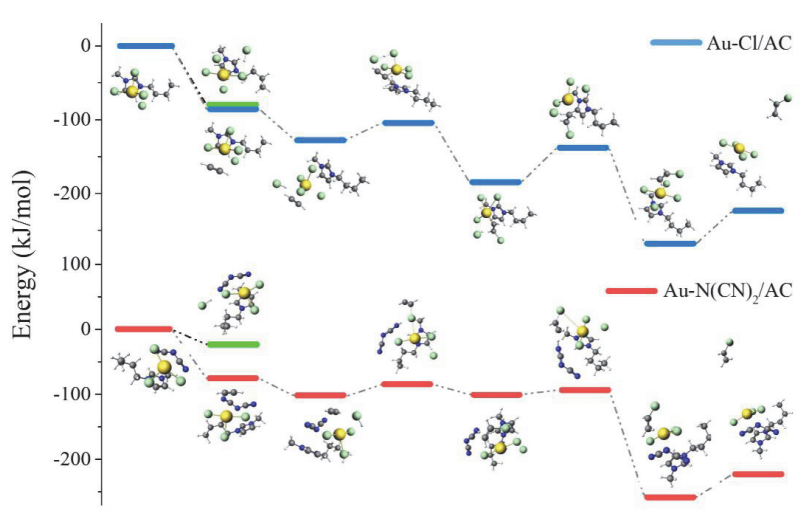

Fig. 7. Reaction pathways of the $\mathrm{Au}-\mathrm{Cl} / \mathrm{AC}$ and $\mathrm{Au}-\mathrm{N}(\mathrm{CN})_{2} / \mathrm{AC}$ catalysts.

was calculated as $-102.51 \mathrm{~kJ} \mathrm{~mol}^{-1}$ for $\mathrm{Au}-\mathrm{N}(\mathrm{CN})_{2} / \mathrm{AC}$ during this adsorption process. Subsequently, the adsorbed $\mathrm{HCl}$ was dissociated to form $\mathrm{N}-\mathrm{H}$ bonds between the $\mathrm{H}$ atom of $\mathrm{HCl}$ and the $\mathrm{N}$ atom of the $\left[\mathrm{N}(\mathrm{CN})_{2}-\right]$ anion with a $\mathrm{N}-\mathrm{H}$ bond length of $1.03 \AA$ in the intermediate (step 4); the $\mathrm{Cl}$ atom of $\mathrm{HCl}$ was slightly closer to the Au atom, which was consistent with the above Hirshfeld charge analysis. Subsequently, the latter intermediate underwent one $\mathrm{Cl}$ atom transfer from the $\mathrm{Au}$ atom to the $\mathrm{C}$ atom of $\mathrm{C}_{2} \mathrm{H}_{2}$, leading to the formation of chlorinated acetylene (step 5). The N-H bond was activated from $1.03 \AA$ to $1.58 \AA$, and the $\mathrm{H}$ atom was close to the $\mathrm{C}$ atom of $\mathrm{C}_{2} \mathrm{H}_{2}$ (step 6). Finally, the product was generated (step 7) and simultaneously released (step 8) to complete the catalytic cycle.

For $\mathrm{Au}-\mathrm{Cl} / \mathrm{AC}, \mathrm{C}_{2} \mathrm{H}_{2}$ was also firstly adsorbed, after which it interacted with gaseous $\mathrm{HCl}$ via step 2 and step 3 (Figure 7). $\mathrm{Next}$, the $\mathrm{Cl}$ atoms from $\mathrm{AuCl}_{4}{ }^{-}$attacked $\mathrm{C}_{2} \mathrm{H}_{2}$ to form a more stable adsorption structure (step 5) via an intermediate (step 4). Subsequently, the $\mathrm{H}$ atom was transferred from $\mathrm{HCl}$ to the $\mathrm{C}$ atom of $\mathrm{C}_{2} \mathrm{H}_{2}$ to form vinyl chloride (step 7) via a transition state (step 6). Meanwhile, the $\mathrm{Cl}$ atom of $\mathrm{HCl}$ was added to the consumed $\mathrm{Cl}$ atom of the $\mathrm{AuCl}_{4}{ }^{-}$structure. Finally, the product was desorbed, and the active catalyst was released to complete the catalytic cycle.

In the proposed reaction pathway of the $\mathrm{Au}-\mathrm{N}(\mathrm{CN})_{2} / \mathrm{AC}$ and $\mathrm{Au}-\mathrm{Cl} / \mathrm{AC}$ catalysts, the dissociation of $\mathrm{HCl}$ and the generation of vinyl chloride were the rate-limiting steps for the catalytic cycle with the requirements of 17 and $44 \mathrm{~kJ} \mathrm{~mol}^{-1}$, respectively. This may explain why the catalytic activity of $\mathrm{Au}-\mathrm{N}(\mathrm{CN})_{2} / \mathrm{AC}$ is higher than that of $\mathrm{Au}-\mathrm{Cl} / \mathrm{AC}$ (Figure 3a). Additionally, the source of $\mathrm{HCl}$ from the gas phase for $\mathrm{Au}-\mathrm{Cl} / \mathrm{AC}$ and its dissociation on $\mathrm{Au}-\mathrm{N}(\mathrm{CN})_{2} / \mathrm{AC}$ should not be ignored. Due to its dissociation by the $\left[\mathrm{N}(\mathrm{CN})_{2}-\right]$ anion, the $\mathrm{HCl}$ is activated, leading to a greater reduction in the adsorption of the chlorinated acetylene intermediate, $\left[\mathrm{Cl}-\mathrm{C}_{2} \mathrm{H}_{2}\right]$, on the $\mathrm{Au}$ site of $\mathrm{Au}-\mathrm{N}(\mathrm{CN})_{2} / \mathrm{AC}$ rather than on that of $\mathrm{Au}-\mathrm{Cl} / \mathrm{AC}$. The adsorption energies of the chlorinated acetylene over $\mathrm{Au}-\mathrm{N}(\mathrm{CN})_{2} / \mathrm{AC}$ and $\mathrm{Au}-\mathrm{Cl} / \mathrm{AC}$ were -100 and $-184 \mathrm{~kJ} \mathrm{~mol}^{-1}$, respectively, indicating that the dissociation of $\mathrm{HCl}$ can significantly inhibit the deactivation pathway of cationic Au reduction caused by the strong adsorption of acetylene. $\mathrm{HCl}$ dissociation by $\mathrm{N}$ ligands had already been reported in the literature [73]. Owing to the low reaction energy required in the rate-limiting steps and the weak adsorption of chlorinated acetylene, Au-N $(\mathrm{CN})_{2} / \mathrm{AC}$ exhibited high catalytic activity and stability toward acetylene hydrochlorination. Additionally, the adsorption energy of $\mathrm{HCl}$ on the individual [Bmim] $\left[\mathrm{N}(\mathrm{CN})_{2}\right]$ IL was calculated to be $-60 \mathrm{~kJ} \mathrm{~mol}^{-1}$, and $\mathrm{HCl}$ could not dissociate at the $\left[\mathrm{N}(\mathrm{CN})_{2}{ }^{-}\right]$anion in the case of no coordination between $\left[\mathrm{N}(\mathrm{CN})_{2}-\right]$ and Au (Figure S14). When $\mathrm{HCl}$ is adsorbed, the Hirshfeld charges of the $\mathrm{N}$ atoms with and without Au show a transfer of 0.040 e (Figure 8a) and 0.023 e (Figure $8 \mathrm{~b})$, respectively, indicating that the $\left[\mathrm{N}(\mathrm{CN})_{2}{ }^{-}\right]$anion is activated by $\mathrm{Au}$ to promote the dissociation of $\mathrm{HCl}$.

\section{Conclusions}

In this study, we systematically investigated the induction and controversial reaction mechanism of the Au-catalyzed hy-

a
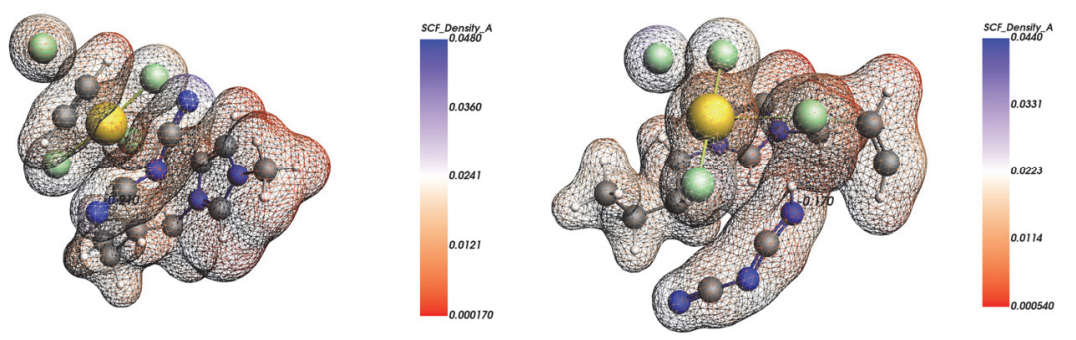

b
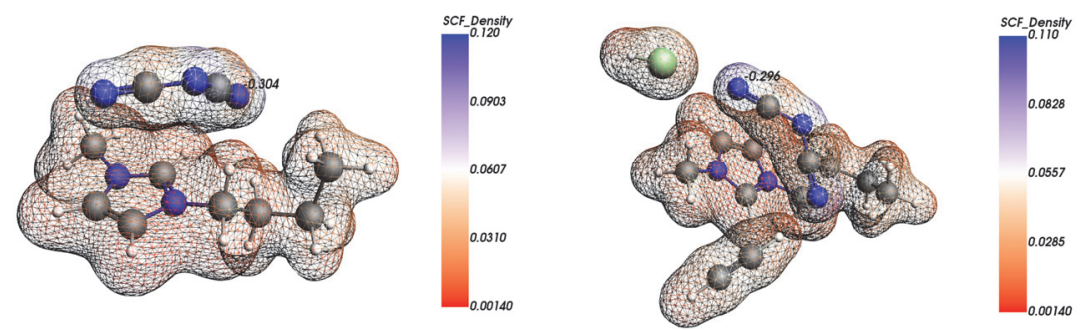

Fig. 8. Hirshfeld charge of the $\mathrm{N}$ atoms before and after $\mathrm{HCl}$ adsorption. (a) $\mathrm{AuCl}_{3}-[\mathrm{Bmim}]\left[\mathrm{N}(\mathrm{CN})_{2}\right]$; (b) $[\mathrm{Bmim}]\left[\mathrm{N}(\mathrm{CN})_{2}\right]$. 
drochlorination of acetylene in a SILP system and successfully prepared Au single-atom catalysts. The reaction induction period of the $\mathrm{Au}-\mathrm{N}(\mathrm{CN})_{2} / \mathrm{AC}$ catalyst could be effectively eliminated due to the relatively high diffusion rate of the substrates in the $[\mathrm{Bmim}]\left[\mathrm{N}(\mathrm{CN})_{2}\right]$ IL layer and the high content of $\mathrm{Au}(\mathrm{III})$ in the $\mathrm{Au}(\mathrm{III}) / \mathrm{Au}(\mathrm{I})$ mixed sites. Owing to the low reaction energy of the rate-limiting steps, the $\mathrm{Au}-\mathrm{N}(\mathrm{CN})_{2} / \mathrm{AC}$ catalyst exhibits high catalytic activity in acetylene hydrochlorination. The activation of the $\left[\mathrm{N}(\mathrm{CN})_{2}-\right]$ anion for stabilizing $\mathrm{Au}$ atoms promotes the dissociation of $\mathrm{HCl}$ and weakens the deactivation of cationic $\mathrm{Au}$ due to the strong adsorption of $\mathrm{C}_{2} \mathrm{H}_{2}$. This work not only provides a new optimization strategy for the mechanism of Au-catalyzed acetylene hydrochlorination but also facilitates the design of Au catalysts and the development of non-Hg catalysts for the manufacture of PVC.

\section{References}

[1] B. Nkosi, N. J. Coville, G. J. Hutchings, M. D. Adams, J. Friedl, F. E. Wagner, J. Catal., 1991, 128, 366-377.

[2] G. J. Hutchings, Catal. Today, 2005, 100, 55-61.

[3] M. Conte, A. F. Carley, C. H. Heirene, D. J. Willock, P. Johnston, A. A. Herzing, C. J. Kiely, G. J. Hutchings, J. Catal., 2007, 250, 231-239.

[4] M. Conte, A. F. Carley, G. A. Attard, A. A. Herzing, C. J. Kiely, G. J. Hutchings, J. Catal., 2008, 257, 190-198.

[5] G. J. Hutchings, Top. Catal., 2008, 48, 55-59.

[6] M. Conte, A. F. Carley, G. J. Hutchings, Catal. Lett., 2008, 124, 165-167.

[7] J. Li, J. T. Fan, S. Ali, G. J. Lan, H. D. Tang, W. F. Han, H. Z. Liu, B. Li, Y. Li, Chin. J. Catal., 2019, 40, 141-146.

[8] Y. Yang, G. J. Lan, X. L. Wang, Y. Li, Chin. J. Catal., 2016, 37, $1242-1248$.

[9] Y. Y. Qiu, S. Ali, G. J. Lan, H. Q. Tong, J. T. Fan, H. Y. Liu, B. Li, W. F. Han, H. D. Tang, H. Z. Liu, Y. Li, Carbon, 2019, 146, 406-412.

[10] S. J. Wang, B. X. Shen, Q. L. Song, Catal. Lett., 2010, 134, 102-109.

[11] W. R. Liu, M. Y. Zhu, B. Dai, New J. Chem., 2018, 42, 20131-20136.

[12] J. L. Zhang, N. Liu, W. Li, B. Dai, Front. Chem. Sci. Eng., 2011, 5, 514-520.

[13] G. Qin, Y. H. Song, R. Jin, J. Shi, Z. Y. Yu, S. K. Cao, Green Chem., 2011, $13,1495-1498$.
[14] H. Y. Zhang, B. Dai, X. G. Wang, W. Li, Y. Han, J. J. Gu, J. L. Zhang, Green Chem., 2013, 15, 829-836.

[15] J. H. Xu, J. Zhao, J. T. Xu, T. T. Zhang, X. N. Li, X. X. Di, J. Ni, J. G. Wang, J. Cen, Ind. Eng. Chem. Res., 2014, 53, 14272-14281.

[16] H. Y. Zhang, W. Li, X. Q. Li, W. Zhao, J. J. Gu, X. Y. Qi, Y. Z. Dong, B. Dai, J. L. Zhang, Catal. Sci. Technol, 2015, 5, 1870-1877.

[17] J. Zhao, B. L. Wang, X. L. Xu, Y. Yu, S. X. Di, H. Xu, Y. Y. Zhai, H. H. He, L. L. Guo, Z. Y. Pan, X. N. Li, J. Catal., 2017, 350, 149-158.

[18] J. Zhao, Y. Yu, X. L. Xu, S. X. Di, B. L. Wang, H. Xu, J. Ni, L. L. Guo, Z. Y. Pan, X. N. Li, Appl. Catal. B, 2017, 206, 175-183.

[19] X. Y. Li, M. Y. Zhu, B. Dai, Appl. Catal. B, 2013, 142-143, 234-240.

[20] M. Conte, C. J. Davies, D. J. Morgan, T. E. Davies, D. J. Elias, A. F. Carley, P. Johnston, G. J. Hutchings, J. Catal., 2013, 297, 128-136.

[21] L. Wang, F. Wang, J. D. Wang, X. L. Tang, Y. L. Zhao, D. Yang, F. M. Jia, T. Hao, React. Kinet. Mech. Catal., 2013, 110, 187-194.

[22] P. Li, H. B. Li, X. L. Pan, K. Tie, T. T. Cui, M. Z. Ding, X. H. Bao, ACS Catal., 2017, 7, 8572-8577.

[23] J. M. Ma, S. J. Wang, B. X. Shen, React. Kinet. Mech. Catal., 2013, 110, 177-186.

[24] K. Zhou, J. C. Jia, C. H. Li, H. Xu, J. Zhou, G. H. Luo, F. Wei, Green Chem., 2015, 17, 356-364.

[25] C. F. Huang, M. Y. Zhu, L. H. Kang, B. Dai, Catal. Commun., 2014, 54, 61-65.

[26] X. Y. Li, Y. Wang, L. H. Kang, M. Y. Zhu, B. Dai, J. Catal., 2014, 311, 288-294.

[27] T. V. Krasnyakova, I. V. Zhikharev, R. S. Mitchenko, V. I. Burkhovetski, A. M. Korduban, T. V. Kryshchuk, S. A. Mitchenko, J. Catal., 2012, 288, 33-43.

[28] S. A. Mitchenko, T. V. Krasnyakova, Kinet. Catal., 2014, 55, 722-728.

[29] Y. F. Pu, J. L. Zhang, X. Wang, H. Y. Zhang, L. Yu, Y. Z. Dong, W. Li, Catal. Sci. Technol., 2014, 4, 4426-4432.

[30] F. Wang, L. Wang, J. D. Wang, Y. L. Zhao, Y. L. Wang, D. Yang, React. Kinet. Mech. Catal., 2014, 114, 725-734.

[31] M. Conte, C. J. Davies, D. J. Morgan, A. F. Carley, P. Johnston, G. J. Hutchings, Catal. Lett., 2014, 144, 1-8.

[32] J. G. Zhao, X. G. Cheng, L. Wang, R. H. Ren, J. J. Zeng, H. H. Yang, B. X. Shen, Catal. Lett., 2014, 144, 2191-2197.

[33] J. Zhao, B. L. Wang, Y. X. Yue, S. X. Di, Y. Y. Zhai, H. H. He, G. F. Sheng, H. X. Lai, Y. H. Zhu, L. L. Guo, X. N. Li, J. Catal., 2018, 365, 153-162.

[34] J. Zhao, B. L. Wang, Y. X. Yue, G. F. Sheng, H. X. Lai, S. S. Wang, L. Yu, Q. F. Zhang, F. Feng, Z. T. Hu, X. N. Li, J. Catal., 2019, 373, 240-249.

[35] Y. Y. Zhai, J. Zhao, X. X. Di, S. X. Di, B. L. Wang, Y. X. Yue, G. F. Sheng,

\section{Graphical Abstract}

Chin. J. Catal., 2021, 42: 334-346 doi: 10.1016/S1872-2067(20)63617-8

\section{Acetylene hydrochlorination over supported ionic liquid phase (SILP) gold-based catalyst: Stabilization of cationic $\mathrm{Au}$ species via chemical activation of hydrogen chloride and corresponding mechanisms}

Jia Zhao*, Saisai Wang, Bolin Wang, Yuxue Yue, Chunxiao Jin, Jinyue Lu, Zheng Fang, Xiangxue Pang, Feng Feng, Lingling Guo, Zhiyan Pan, Xiaonian Li *

Zhejiang University of Technology

Cationic $\mathrm{Au}$ species coordinate with $[\mathrm{Bmim}]\left[\mathrm{N}(\mathrm{CN})_{2}\right]$ to form strong $\mathrm{Au}$-IL complexes, which greatly increase the thermal and reaction stability of Au-based catalysts.

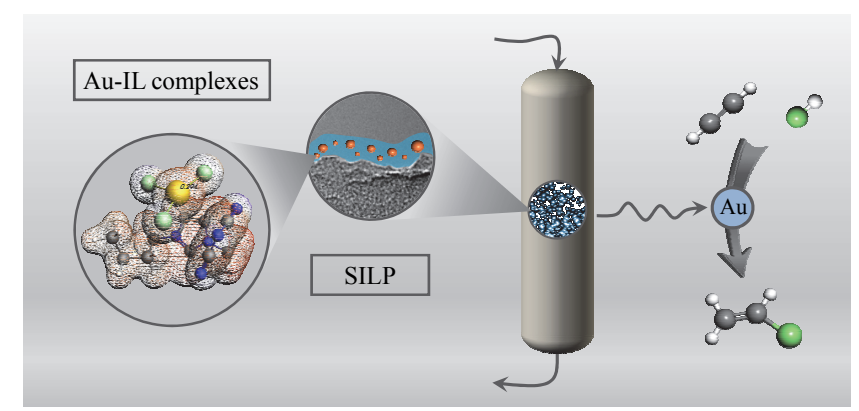


H. X. Lai, L. L. Guo, H. Wang, X. N. Li, Catal. Sci. Technol., 2018, 8, 2901-2908.

[36] G. Malta, S. A. Kondrat, S. J. Freakley, C. J. Davies, L. Lu, S. Dawson, A. Thetford, E. K. Gibson, D. J. Morgan, W. Jones, P. P. Wells, P. Johnston, C. R. A. Catlow, C. J. Kiely, G. J. Hutchings, Science, 2017, 355, 1399-1403.

[37] G. Malta, S. A. Kondrat, S. J. Freakley, C. J. Davies, S. Dawson, X. Liu, L. Lu, K. Dymkowski, F. Fernandez-Alonso, S. Mukhopadhyay, E. K. Gibson, P. P. Wells, S. F. Parker, C. J. Kiely, G. J. Hutchings, ACS Catal., 2018, 8, 8493-8505.

[38] K. Zhou, W. Wang, Z. Zhao, G. H. Luo, J. T. Miller, M. S. Wong, F. Wei, ACS Catal., 2014, 4, 3112-3116.

[39] H. Xu, K. Zhou, J. K. Si, C. H. Li, G. H. Luo, Catal. Sci. Technol., 2016, 6, 1357-1366.

[40] M. Y. Zhu, Q. W. Wang, K. Chen, Y. W. Wang, C. H. Huang, H. Dai, F. Yu, L. H. Kang, B. Dai, ACS Catal., 2015, 5, 5306-5316.

[41] P. Johnston, N. Carthey, G. J. Hutchings, J. Am. Chem. Soc., 2015, 137, 14548-14557.

[42] X. H. Tian, G. H. Hong, B. B. Jiang, F. P. Lu, Z. W. Liao, J. D. Wang, Y. R. Yang, RSC Adv., 2015, 5, 46366-46371.

[43] A. Goguet, C. Hardacre, I. Harvey, K. Narasimharao, Y. Saih, J. Sa, J. Am. Chem. Soc., 2009, 131, 6973-6975.

[44] X. Duan, X. Tian, J. Ke, Y. Yin, J. Zheng, J. Chen, Z. Cao, Z. Xie, Y. Yuan, Chem. Sci., 2016, 7, 3181-3187.

[45] X. Duan, Y. Yin, X. Tian, J. Ke, Z. Wen, J. Zheng, M. Hu, L. Ye, Y. Yuan, Chin. J. Catal., 2016, 37, 1794-1803.

[46] S. S. Shang, W. Zhao, Y. Wang, X. Y. Li, J. L. Zhang, Y. Han, W. Li, ACS Catal., 2017, 7, 3510-3520.

[47] Y. Li, Y. Z. Dong, W. Li, Y. Han, J. L. Zhang, Mol. Catal., 2017, 443, 220-227.

[48] B. L. Wang, H. X. Lai, Y. X. Yue, G. F. Sheng, Y. Q. Deng, H. H. He, L. L. Guo, J. Zhao, X. N. Li, Catalysts, 2018, 8, 351/1-351/13.

[49] S. Werner, N. Szesni, A. Bittermann, M. J. Schneider, P. Härter, M. Haumann, P. Wasserscheid, Appl. Catal. A, 2010, 377, 70-75.

[50] A. Wei $\beta$, M. Giese, M. Lijewski, R. Franke, P. Wasserscheid, M. Haumann, Catal. Sci. Technol., 2017, 7, 5562-5571.

[51] J. Zhao, Y. X. Yue, G. F. Sheng, B. L. Wang, H. X. Lai, S. X. Di, Y. Y. Zhai, L. L. Guo, X. N. Li, Chem. Eng. J., 2019, 360, 38-46.

[52] Y. X. Yue, B. L. Wang, G. F. Sheng, H. X. Lai, S. S. Wang, Z. Chen, Z.-T. Hu, J. Zhao, X. N. Li, New J. Chem., 2019, 43, 12767-12775.

[53] Y. Q. Cen, Y. X. Yue, S. S. Wang, J. Y. Lu, B. L. Wang, C. X. Jin, L. L. Guo, Z.-T. Hu, J. Zhao, Catalysts, 2020, 10, 24/1-24/14.

[54] M. Haumann, K. Dentler, J. Joni, A. Riisager, P. Wasserscheid, Adv. Synth. Catal., 2007, 349, 425-431.

[55] M. Marchetti, C. Botteghi, S. Paganelli, M. Taddei, Adv. Synth. Catal., 2003, 345, 1229-1236.

[56] L. Naicker, H. B. Friedrich, A. Govender, P. Mohlala, Appl. Catal. A, 2018, 562, 37-48.

[57] J. Brünig, Z. Csendes, S. Weber, N. Gorgas, R. W. Bittner, A.
Limbeck, K. Bica, H. Hoffmann, K. Kirchner, ACS Catal., 2018, 8, 1048-1051.

[58] T. Yasuda, E. Uchiage, T. Fujitani, K. Tominaga, M. Nishida, Appl. Catal. B, 2018, 232, 299-305.

[59] P. Z. Zhang, Z. B. Jiang, Y. H. Cui, G. Q. Xie, Y. Z. Jin, L. L. Guo, Y. Q. Xu, Q. F. Zhang, X. N. Li, Appl. Catal. B, 2019, 255, $117757 / 1-117757 / 10$.

[60] R. Kukawka, A. Pawlowska-Zygarowicz, J. Dzialkowska, M. Pietrowski, H. Maciejewski, K. Bica, M. Smiglak, ACS Sustain. Chem. Eng., 2019, 7, 4699-4706.

[61] J. J. Peng, J. Y. Li, Y. Bai, H. Y. Qiu, K. Z. Jiang, J. X. Jiang, G. Q. Lai, Catal. Commun., 2008, 9, 2236-2238.

[62] J. Zhao, S. C. Gu, X. L. Xu, T. T. Zhang, Y. Yu, X. X. Di, J. Ni, Z. Y. Pan, X. N. Li, Catal. Sci. Technol, 2016, 6, 3263-3270.

[63] J. Oliver-Meseguer, A. Domenech-Carbo, M. Boronat, A. Leyva-Perez, Angew. Chem. Int. Ed., 2017, 56, 6435-6439.

[64] S. X. Di, Y. Q. Xu, Q. F. Zhang, X. L. Xu, Y. Y. Zhai, B. L. Wang, H. H. He, Q. T. Wang, H. Xu, Y. S. Jiang, J. Zhao, X. N. Li, RSC Adv., 2018, 8, 24094-24100.

[65] B. L. Wang, J. Zhao, Y. X. Yue, G. F. Sheng, H. X. Lai, J. Y. Rui, H. H. He, Z. T. Hu, F. Feng, Q. F. Zhang, L. L. Guo, X. N. Li, ChemCatChem, 2019, 11, 1002-1009.

[66] K. C. O’Connell, J. R. Monnier, J. R. Regalbuto, Appl. Catal. B, 2018, $225,264-272$.

[67] L. Wang, B. X. Shen, J. J. Zhao, X. T. Bi, Can. J. Chem. Eng., 2017, 95, 1069-1075.

[68] J. Liu, G. J. Lan, Y. Y. Qiu, X. L. Wang, Y. Li, Chin. J. Catal., 2018, 39, 1664-1671.

[69] J. Zhao, J. T. Xu, J. H. Xu, T. T. Zhang, X. X. Di, J. Ni, X. N. Li, Chem. Eng. J., 2015, 262, 1152-1160.

[70] L. Ye, X. P. Duan, S. Wu, T. S. Wu, Y. X. Zhao, A. W. Robertson, H. L. Chou, J. W. Zheng, T. Ayvali, S. Day, C. Tang, Y. L. Soo, Y. Z. Yuan, S. C. E. Tsang, Nat. Commun., 2019, 10, 914/1-914/10.

[71] X. P. Duan, L. C. Ning, Y. Yin, Y. T. Huang, J. Gao, H. Q. Lin, K. Tan, H. H. Fang, L. M. Ye, X. Lu, Y. Z. Yuan, ACS Appl. Mater. Interfaces, 2019, 11, 11317-11326.

[72] H. X. Lai, B. L. Wang, Y. X. Yue, G. F. Sheng, S. S. Wang, F. Feng, Q. F. Zhang, J. Zhao, X. N. Li, ChemCatChem, 2019, 11, 3318-3326.

[73] S. K. Kaiser, R. Lin, S. Mitchell, E. Fako, F. Krumeich, R. Hauert, O. V. Safonova, V. A. Kondratenko, E. V. Kondratenko, S. M. Collins, P. A. Midgley, N. Lopez, J. Pérez-Ramírez, Chem. Sci., 2019, 10, 359-369.

[74] J. Zhao, J. T. Xu, J. H. Xu, J. Ni, T. T. Zhang, X. L Xu, X. N. Li, ChemPlusChem, 2015, 80, 196-201.

[75] A. F. Claudio, A. M. Ferreira, S. Shahriari, M. G. Freire, J. A. Coutinho, J. Phys. Chem. B, 2011, 115, 11145-11153.

[76] R. Santiago, J. Bedia, D. Moreno, C. Moya, J. de Riva, M. Larriba, J. Palomar, Sep. Purif. Technol., 2018, 204, 38-48.

[77] R. Lin, S. K. Kaiser, R. Hauert, J. Pérez-Ramírez, ACS Catal., 2018, 8, 1114-1121.

\title{
乙炔氢氯化反应中的负载金-离子液体催化剂：离子态金物种的稳定机制
}

\author{
赵 佳 ${ }^{\mathrm{a},}{ }^{*}$ ，王赛赛 ${ }^{\mathrm{a}}$ ，王柏林 ${ }^{\mathrm{a}, \mathrm{b}}$ ，岳玉学 ${ }^{\mathrm{a}}$, 金春晓 ${ }^{\mathrm{a}}$, 陆金跃 ${ }^{\mathrm{a}}$, 方 正 $^{\mathrm{a}}$, 庞祥雪 ${ }^{\mathrm{a}}$, \\ 丰 枫 ${ }^{\mathrm{a}}$, 郭伶伶 ${ }^{\mathrm{a}}$, 潘志彦 ${ }^{\mathrm{b}}$, 李小年 ${ }^{\mathrm{a}, \#}$ \\ a浙江工业大学工业催化研究所, 浙江杭州 310014 \\ b 浙江工业大学环境工程学院, 浙江杭州 310014
}

摘要: 聚氯乙烯(PVC)作为世界通用工程塑料之一, 具有优异的物理、化学和机械性能, 在工业、农业、建筑、包装、电力 等行业中应用广泛. 氯乙烯是生产聚氯乙烯的重要单体. 氯乙烯的生产主要有电石法和乙烯法两种工艺路线, 由于我国 
“贫油、富煤、少气”的资源现状, 电石法产能占全部产能的 $83 \%$ 以上. 电石法生产氯乙烯的原理是在氯化录催化剂存在下, 将电石水解精制后的乙炔气与氯化氢加成直接合成氯乙烯. 随着节能减排及环保要求的逐渐提高和国际涉录公约的实施, 开发新一代绿色无录催化剂具有重要的战略意义. 近年来, 金基催化剂是无录催化剂基础研究和技术开发中最重要的方 向. 在之前的工作中, 我们课题组首先报道了负载离子液体-金催化剂体系(Au-SILP)在电石法生产氯乙烯工艺中的应用, 并发现离子液体的存在可以显著提高金活性物种在载体表面的分散度和稳定其化学价态. 在后续研究中, 我们在负载离 子液体-金催化体系中引入金属铜离子 $\left(\mathrm{Cu}^{2+}\right)$, 利用反应过程中 $\mathrm{Au}-\mathrm{Cu}$ 之间的氧化还原循环, 设计并制备了金属铜基配位离 子液体, 构建了负载离子液体-金-铜催化剂体系. 铜离子的引入形成了一个催化剂自身维持氧化态的微环境, 实现了被还 原金物种的原位氧化再生.

本文在上述研究基础上, 利用配位离子液体 $[\mathrm{Bmim}]\left[\mathrm{N}(\mathrm{CN})_{2}\right]$ 中 $\left[\mathrm{N}(\mathrm{CN})_{2}{ }^{-}\right]$阴离子和阳离子金之间的强配位作用, 构建出 比Au-Cl键更稳定的 $\mathrm{Au}-\mathrm{N}$ 键, 并通过X射线光电子能谱(XPS)、球差校正-扫描透射电镜(AC-STEM)和扩展X射线吸收精细 结构(EXAFS) 表征证明了 $\mathrm{Au}$ 以单原子状态存在于载体表面. 制备的 $\mathrm{Au}-\mathrm{N}(\mathrm{CN})_{2} / \mathrm{AC}$ 催化剂在乙炔氢氯化反应中表现出比 $\mathrm{Au}-\mathrm{Cl} / \mathrm{AC}$ 和 $\mathrm{Au} / \mathrm{AC}$ 催化剂更高的稳定性和催化活性以及更短的诱导期. 进一步表征分析发现, $\left[\mathrm{N}(\mathrm{CN})_{2}{ }^{-}\right]$配体促进了阳离 子金和配体之间的电子转移, 提高了阳离子金的电子云密度, 削弱了乙炔在阳离子金上的吸附强度, 抑制了其还原, 提高了 催化剂的稳定性. 更重要的是, 与阳离子金配位的 $\left[\mathrm{N}(\mathrm{CN})_{2}\right]^{-}$配体使得反应过程中的氯化氢在氮位点发生化学解离, 促进了 氯化氢活化, 同时降低了反应能垒. 对负载配位离子液体-金催化体系反应诱导期的分析结果表明, 反应诱导期与反应物 (乙炔、氯化氢)分子在离子液体层中的溶解度无关, 而主要取决于催化剂中 $\mathrm{Au}(\mathrm{III})$ 物种的含量和反应物分子在离子液体中 的扩散速率. 上述研究结果进一步深化了离子液体和活性金物种之间电子的作用机理, 建立了负载离子液体-金催化剂体 系对反应物的活化机制和反应机理, 为进一步开发具有工业应用价值的乙炔氢氯化反应无录催化剂提供了科学基础和参 考.

关键词: 乙炔氢氯化; 电子密度; 氯化氢活化; 稳定机理; 金基负载离子液体相催化剂

收稿日期: 2020-03-21. 接受日期: 2020-05-10. 出版日期: 2021-02-05.

*通讯联系人. 电话: (0571)88871565; 电子信箱: jiazhao@zjut.edu.cn

通讯联系人. 电话: (0571)88320002; 电子信箱: xnli@zjut.edu.cn

基金来源：国家自然科学基金(21606199); 浙江省科技厅(LGG20B060004).

本文的电子版全文由Elsevier出版社在ScienceDirect上出版(http://www.sciencedirect.com/science/journal/18722067). 